Review

\title{
Tree Crops, a Permanent Agriculture: Concepts from the Past for a Sustainable Future
}

\author{
Thomas J. Molnar ${ }^{1, *}$, Peter C. Kahn ${ }^{2}$, Timothy M. Ford ${ }^{3}$, Clarence J. Funk ${ }^{4}$ and \\ C. Reed Funk ${ }^{1,4, \dagger}$
}

1 Department of Plant Biology and Pathology, Rutgers University, Foran Hall, 59 Dudley Road, New Brunswick, NJ 08901, USA

2 Department of Biochemistry \& Microbiology, Rutgers University, Lipman Hall, 76 Lipman Drive, New Brunswick, NJ 08901, USA; E-Mail: kahn@aesop.rutgers.edu

3 Pineview Farms, L.L.C. P.O. Box 10, Huntsville, UT 84317, USA; E-Mail: tcford3@aol.com

4 Improving Perennial Plants for Food and Bioenergy, 711 S State Street, Richmond, UT 84333, USA; E-Mail: cfunk@san.rr.com

$\dagger$ Deceased.

* Author to whom correspondence should be addressed; E-Mail: molnar@aesop.rutgers.edu; Tel.: +1-848-932-6330; Fax: +1-732-932-9441

Received: 29 June 2013; in revised form: 26 August 2013 / Accepted: 26 August 2013 /

Published: 30 September 2013

\begin{abstract}
J. Russell Smith (1874-1966), a professor of geography at Columbia University, witnessed the devastation of soil erosion during his extensive travels. He first published his landmark text, Tree Crops, A Permanent Agriculture in 1929, in which he described the value of tree crops for producing food and animal feed on sloping, marginal, and rocky soils as a sustainable alternative to annual crop agriculture less suited to these lands. A cornerstone of his thesis was using wide germplasm collection and plant breeding to improve this largely underutilized and genetically unexploited group of plants to develop locally adapted, high-yielding cultivars for the many climatic zones of North America. Smith proposed an establishment of "Institutes of Mountain Agriculture" to undertake this work. For a variety of reasons, though, his ideas were not implemented to any great degree. However, our growing population's increasing demands on natural resources and the associated environmental degradation necessitate that Smith's ideas be revisited. In this review, his concepts, supported by modern scientific understanding and advances, are discussed and expanded upon to emphasize their largely overlooked potential to enhance
\end{abstract}


world food and energy security and environmental sustainability. The discussion leads us to propose that his "institutes" be established worldwide and with an expanded scope of work.

Keywords: perennial crops; sustainable agriculture; plant breeding; genetic resources; food security; energy security; land restoration

\section{Introduction}

Soil, an essential and valuable resource, developed and was maintained under the cover of forests and perennial grasslands. Much of this vital inheritance has been lost to deforestation, overgrazing, unwise tillage, and desertification [1-6]. The replacement of native perennial species with cultivated annual crops has been the cause of much of this destruction [3,6,7]. J. Russell Smith (1874-1966), then a professor of geography at Columbia University, witnessed the devastation of soil erosion during his extensive travels. He published his landmark book "Tree Crops, A Permanent Agriculture" in 1929 with an update in 1950 [8]. In this book he discussed the value of genetically improved tree crops for producing feed for animals and food for people, while rebuilding, enhancing, and maintaining soils. Based on observations of the highly productive, steeply sloped chestnut (Castanea sativa Mill.) forests of Corsica, Smith envisioned the development of numerous tree species for production of crops on mountainous, dry, or rocky land unsuitable for the sustainable production of annually planted crops. He discussed in detail the merits of many species with potential for producing feed for livestock, such as honey locust (Gleditsia triacanthos L.), mulberry (Morus spp.), persimmon (Diospyros spp.), chestnut (Castanea spp.), oak (Quercus spp.), carob (Ceratonia siliqua L.), and others, in addition to species producing nutritious food for humans, including walnuts (Juglans spp.), pecan (Carya illinoinensis [Wangenh.] K.Koch), hickories (Carya spp.), almond (Prunus dulcis [Mill.] D.A. Webb), hazelnuts (Corylus spp.), and more. Smith recognized the great importance of plant breeding in developing this expanded agricultural system. He proposed extensive expeditions for germplasm collection and the establishment of a foundation for the long-term support of numerous "Institutes of Mountain Agriculture" These institutes would conduct tree-crop breeding and research at various strategic locations throughout the USA, concentrating on species best adapted to each region.

Unfortunately, the foundation Smith proposed was never established, and the advancement of tree crops for the production of food and feed on degraded, marginal, and sloping land remains greatly underdeveloped. Smith wrote his book prior to the Green Revolution, an extremely productive period that reduced the perceived need to develop new crops for expanding future food production. During the period from 1950 to 2004, world grain production more than tripled, soybean production increased nine times, and meat production increased almost five times [9]. Especially striking was that these increases were achieved with only a small rise in the land area devoted to crop production. Nutritious, highly palatable food and other agricultural products were thus made available at the lowest inflation-adjusted cost in human history, making the development of tree crop agriculture, appear less urgent.

In addition, and of equal importance, tree crop agriculture does not lend itself to an industrial agriculture model as well as annuals do. Some tree species bear good crops one year and then a small or no crop for the next one or two years $[9,10]$. The shells of some nut species are hard to crack, 
raising production costs, and some have a low kernel to shell ratio, also raising costs $[11,12]$. Perennial crop plants also require longer times as well as more labor for cultivar development than annuals [13]. Yet another factor, as pointed out by Smith in 1929, has been a lack of long term vision on the part of policy makers, a problem which continues today. One manifestation of this is that U.S. price and farm income support programs do not include tree nuts [14], although "specialty crops", of which nuts are an example, do qualify for a number of indirect support programs. MacDaniels and Lieberman have discussed some of the problems that have inhibited tree crop development. They point out that as of 1979, when they published their paper, "long-term research projects on tree crops are practically non-existent" [15].

Since 1950, however, the world's population has risen from 2.6 billion to 7 billion. Along with population growth and prosperity came major increases in demand for energy, which has been met with a substantial rise in the consumption of fossil fuels (the use of oil increased 7.3 times, coal 2.1 times, and natural gas 12.3 times during this period) [16]. This increased use of fossil fuels, combined with widespread deforestation, unwise tillage, overgrazing, and erosion of soils, has dramatically increased the level of carbon dioxide and other greenhouse gases in the atmosphere [3,5-7,17-19].

As the population continues to grow (it may reach nine billion by 2050 [20]), the ability to produce enough food for an additional two billion people, eliminate hunger, improve diets, and provide the necessary amounts and varieties of agricultural products desired by increasingly affluent societies is in question. Meeting these future needs, especially if grain crops continue to be used as a source of bioenergy, will require an increase in agricultural productivity even greater than that achieved during the Green Revolution [21]. While much of the world's agriculture continues to be highly productive [22], it is unlikely that the required increase will be met using current policies and practices [23-29].

Furthermore, production of annual crops in many regions is not sustainable over the long term, as it is associated with leaching of fertilizers and pesticides, soil erosion, reductions in soil organic matter, salinization, desertification, and reliance on diminishing or non-renewable groundwater [3,7,26,30-36]. In addition, the world depends on only a few annual cereals and grain legumes for a majority of its food supply [37]. A failure of any one of these crops would have calamitous effects worldwide. The emerging, extremely virulent race Ug99 of wheat stem rust (Puccinia graminis f. sp. tritici) presents a sobering example. This new race was first observed in Uganda, Africa in 1999 on wheat lines expressing the stem rust resistance gene Sr31, a widely utilized gene for which no virulence had been reported previously. A high percentage of the world's major wheat cultivars are susceptible to Ug99. It continues to move north and east out of Uganda. It has been reported in Yemen on the Arabian Peninsula on a likely path to the major wheat belt of Asia [38]. It is believed that severe infection can lower yields by $40 \%$ or more. If this race reaches India's Punjab region before resistant cultivars can be developed, losses may come to $\$ 3$ billion per year and $\$ 10$ billion if it reaches the U.S. (not to mention how this will affect food supplies) [39].

Our growing demands for finite fossil fuel resources [40,41], their rising prices, and major environmental risks associated with their acquisition and use will inevitably require the wider development of alternative sources of energy. Recent and projected advances in conversion technologies and environmental benefits suggest plant biomass will play an ever-increasing role in meeting demands for non-fossil fuel energy sources [42-50]. However, production of bioenergy crops on tillable farmland competes with food production, raises prices, and can lead to increased 
unsustainable cropping of annual species on marginal lands. This could hasten the crisis of an expanding population outgrowing its food production capacity. Figure 1 illustrates the problem.

Figure 1. World production of cereal crops and grain production per person. Circles in (a) 1961-2005 [51]; and (b) 1950, 1955 and 1960 [52]; Squares in (a) data prior to 2005 from [53]; and (b) Data for 2005 and 2006 from [54]. The points for 2005 and 2006 are estimated by the authors of the FAO study. The dashed line in (a) is a linear regression of the data from 1961 to 1980 . The lower slope prior to 1960 is probably due to the fact that the Green Revolution did not show full worldwide effect until then. Note the lowering of the slope that began in the 1990s in (a) and the downward turn that began in the 1980s in (b).
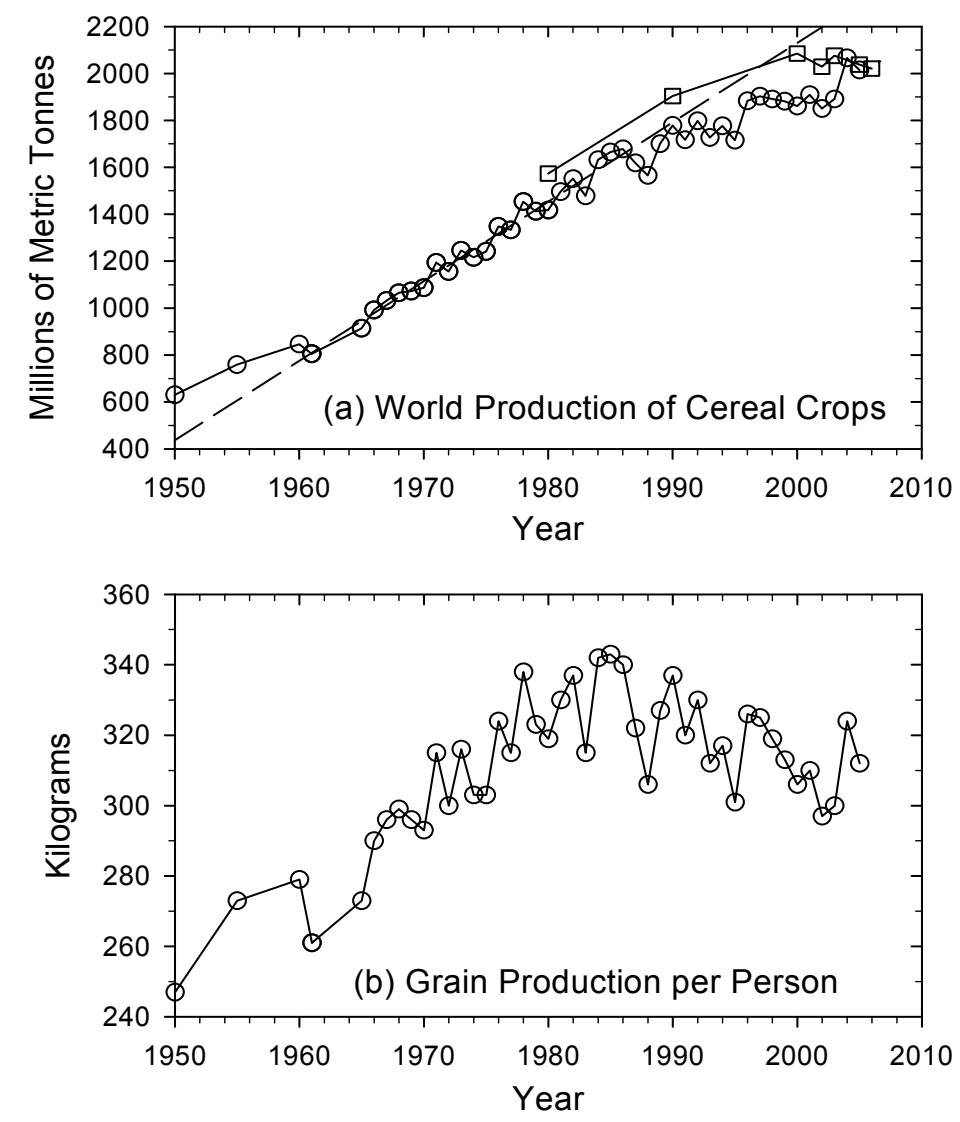

Unless a balanced solution is found, more frequent food shortages, reductions in quality of life, and increased environmental degradation loom in the near future. It is here where J. Russell Smith's “Tree Crops, A Permanent Agriculture"[8] must be revisited.

In this review, Smith's concepts - supported by modern scientific understanding and advances — are discussed and expanded upon to emphasize their largely overlooked potential to enhance world food and energy security and environmental sustainability. Application of his concepts is supported by the discussion of promising, yet underutilized, examples of temperate zone nut tree crops and tropical species that are currently foci of genetic improvement projects underway around the world or that are good candidates for development. We will end with a proposal for the worldwide implementation of an expanded version of Smith's ideas. 


\section{Perennial Crops Remain an Underutilized Resource}

As Smith envisioned, advances in tree and other perennial crop breeding have the potential, if properly implemented, to dramatically increase the world's sustainable food production capacity. This can be achieved by developing a variety of perennial species, including tree crops and grasses, legumes, and other forbs, to produce nutritious food on hundreds of millions of hectares of steep, rocky slopes, degraded forests and rangelands, and marginal farmlands unsuitable for sustainable production of annual crops. No virgin forests would need to be cut, as vast areas of currently deforested or otherwise degraded land exist throughout the world, with 850 million hectares of degraded lands reported to be found in the tropics [4,55-57]. Planting these lands to improved tree and other perennial crops would return some or many of the environmental and ecological services once provided by the forests. Perennial crops can also be produced in home gardens, edible landscapes [58], parks, waterways, and along roadsides, as well as in small towns, suburbs, cities, and other places not currently growing plants for food. Overall, this approach could greatly increase and diversify food supplies, while providing a means to alleviate many of the environmental and ecological problems likely to arise if mid-century water and food needs are met using an expansion and intensification of our current agricultural system [7,25,26,28,59,60].

As mentioned above, modern agriculture is highly dependent, directly or indirectly, on fossil fuels. Therefore, food security cannot be fully addressed without also considering energy security. Fortunately, tree crops and other perennials also hold promise as a significant source of sustainable bioenergy. A wide diversity of perennials exists that can be improved and grown for the production of biomass and/or oil on extensive lands not suitable for the cultivation of annual crops. Production on these lands would greatly reduce competition with food crops on our limited tillable land. Biomass can produce electricity and heat directly through combustion, or it can be converted to liquid fuels or methane through available and improving technologies such as gasification, fast pyrolysis, fermentation, and by enzymatic means [61-64]. Energy derived from perennial biomass has many environmental and economic benefits, especially when it is used in replacement of fossil fuels. It can be carbon neutral or better, as perennial plants harvest, utilize, and recycle existing carbon dioxide, while building soil organic matter, a storehouse of carbon $[6,65]$. Estimates of the loss of soil organic carbon (SOC) from the world's soils range widely from 44 to $535 \mathrm{pgC}\left(1 \mathrm{pg}=10^{15} \mathrm{~g}=1\right.$ gigatonne), with a common range of 55 to $78 \mathrm{pgC}$. The total amount of atmospheric carbon is estimated to be $760 \mathrm{pgC}$. The process of SOC depletion can be reversed with non-till agriculture and the use of perennial crops. Recovery of a significant fraction of lost carbon will increase soil fertility, improve water quality, reduce reservoir and waterway sedimentation and help alleviate global climate change [6]. Soil organic matter is often the most limiting factor to enhanced growth. Furthermore, biomass is essentially free from sulfur and heavy metals and can be readily stored until needed - an advantage over many other renewable energy sources $[42,49,66-68]$.

J. Russell Smith believed our expanding requirements for animal feed would provide a nearly unlimited market for tree crops. While this point remains true, his ideas can be built upon to exploit today's virtually unlimited market for energy. The rising costs and use of fossil fuels and food commodities are making the production of bioenergy economically competitive. Utilizing perennial biofuels for energy production, in addition to their potential environmental benefits (if implemented 
correctly), would diversify fuel supplies and help stabilize or reduce the price of oil. Curtis and Ehrenfeld have discussed the combined effects of rising oil prices and transport infrastructure damage due to climate change [69]. They note that as the oil supply either declines or extraction becomes too difficult or too environmentally damaging, global supply networks may have to shrink due to the increased costs of long distance transport. Supply chains, now global and complex, would become simpler and more regional and local. Much manufacturing and food production would be done closer to where the products are consumed. Fortunately bioenergy lends itself more readily to decentralized production than energy from fossil fuels.

If properly executed, development of locally or regionally diverse biofuel supplies could employ millions, provide a huge economic boon for farmers and rural economies, curb urban migration, and reduce trade disputes. Many of these social benefits have been demonstrated with the production of sugarcane in Brazil and oil palm in Malaysia [70,71]. One hundred million hectares of oil palm producing five tons of oil per hectare would yield 500 million tons of oil per year indefinitely. Two hundred million hectares could produce more vegetable oil than the combined yearly production of petroleum from Saudi Arabia, Iran, Nigeria, and Venezuela. Oil palm plantations also produce 20 to $30 \mathrm{t}$ of dry biomass per hectare annually, which can be converted to bioenergy and other useful products during and especially at the end of each 25 year rotation. Plant breeding and best agricultural practices should allow continued yield increases (current average world yield $=3.4 \mathrm{t}$ of oil per hectare) [72]. The authors do not advocate that oil palm be planted on such a large scale, especially on sensitive tropical lands and especially in huge monocrop tracts; its striking production potential is described here simply to indicate the magnitude of biofuel possibilities. We are also aware that some forms of oil palm cultivation have come under criticism because of environmentally destructive practices [73-76]. Like any agricultural method, it need not be done badly [77,78]. Export earnings and other revenues from the sale of biofuels could allow the developing world to purchase needed inputs to utilize the best agricultural practices and to improve health, education, nutrition, and ultimately the quality of life of hundreds of millions of people. Furthermore, unlike fossil fuels, biomass-based energy could be produced indefinitely, if properly managed.

Unlike the dozen or so cultivated annual species on which much of the world's food security depends, hundreds of useful tree crops and perennial grasses, shrubs, legumes and other forbs exist that have undergone very few cycles (if any) of controlled breeding. As such, they remain genetically diverse and present considerable opportunities for rapid and substantial improvements in adaptation to new and harsh environments, pest and disease resistance, yield, nutritional value, and other characteristics. Conventional plant breeding supported by advances in genetics, molecular biology, ecology, and propagation technologies, as well as growing access to worldwide germplasm resources, will provide the means to more quickly increase the usefulness of numerous species. This approach is well proven, as was clearly demonstrated by the successes of the Green Revolution, and when supplemented with today's advancing technologies [79,80], should prove even more efficient, effective, and possibly far-reaching when applied to perennial crops. A striking successful example is the "FasTrack" breeding system being developed at the Appalachian Fruit Research Station in Kearneysville, West Virginia. A fast flowering gene from Poplar (Populus spp.) has been isolated and transformed into plum (Prunus spp.) to successfully shorten the breeding cycle from four to five years to only one year, with similar work underway for apples (Malus domestica Borkh.) and other 
fruit trees [81]. There is no reason why the method could not be applied to other tree crops, including nuts. Furthermore, the genomes of a number of valuable tree species, including peach (Prunus persica L.), apple, poplar (Populus trichocarpa), oak (Quercus spp.), beech (Fagus spp.) chestnut (Castanea spp.), and hazelnut (Corylus avellana L.), already have been sequenced, or are currently underway [82-85]. Having access to the genome sequence data will provide for the development of more efficient genetic improvement methods, including genomic selection, as well as better understanding of genetic diversity, population structure, and host-pathogen interactions, including inherent resistances and susceptibilities.

Genomic selection (GS) will prove particularly useful for at least two reasons. It will allow us to be much more selective in the plant material that we raise until maturity, making breeding more efficient and cost effective. Secondly, unlike marker assisted selection, which is excellent for identifying and working with alleles that have large effects, GS allows analysis of complex characteristics which are governed by combinations of many genes each of small effect [86]. Yield, stress tolerance and crop quality, among others, are traits of this kind. When the first tree genome (poplar) was announced in 2003 [87] and released in 2004 [88] the prospect of improvement in these characteristics, among others, was emphasized.

Besides the obvious benefits such as the reduced erosion and disruption of the soil biota and organic matter to soils that are not tilled each year, perennials possess a number of other characteristics that can be enhanced to provide a highly productive and sustainable form of agriculture. Perennial plants generally exhibit a much longer period of photosynthetic activity than annuals each year, as they often initiate growth rapidly in the spring and provide complete soil coverage many weeks earlier and maintain it longer into the fall. This dramatic difference can be observed in the corn belt region of the U.S. in the spring and after harvest when comparing agricultural lands planted to corn or soybeans to lands covered in perennial vegetation [29]. In addition to a longer time to convert solar energy into plant biomass, their more extensive yearly leaf canopy, litter layer, deeper root systems, and dormant vegetation limits soil loss from water runoff, raindrop splash, and wind, while also allowing for improved infiltration of water into soils [89-91]. Improved water infiltration, besides reducing runoff, maximizes access to natural precipitation and reduces the need for supplemental irrigation, and it recharges groundwater aquifers, most of which are presently being drained faster than they refill [34].

Perennials also have advantages in terms of nutrient and water management. Annuals often require applications of starter fertilizers each year which are not required for perennials and much of which is susceptible to leaching out of the soil into rivers, streams, lakes and the ocean before being assimilated by the plant. In addition, many woody perennials conserve and recycle nutrients via storage in long-lived stem and root tissues, along with the remobilization of nutrients from senescing leaf canopies in the fall from mobilization back into the trunk and roots, thereby aiding rapid leafing out in the spring and from decomposition of dead and dying plant material [92,93]. Thus, if grown in the appropriate manner, many perennial species may be produced with fewer inputs than annuals without experiencing a reduction in soil fertility [48,94-100]. Their productivity is further supported by deep root systems that provide for improved water uptake and tolerance of short-term droughts. Perennial root systems are active throughout much of the year and extract nutrients and minerals from larger volumes of soil at depths greater than most annuals [91]. As a result, perennial crops generally reduce nutrient leaching and the discharge of nitrous oxide, a potent greenhouse gas [7,35,96,101,102]. The major environmental and health effects of nitrogen pollution are well known and are clearly demonstrated by 
the hypoxic dead zones in the Gulf of Mexico and elsewhere [103]. Randall et al. showed that losses of nitrate nitrogen in subsurface water drainage from annual row crops were 30-50 times greater than those from land planted in perennials such as alfalfa (Medicago sativa L. and M. falcata L.) or in the Conservation Reserve Program (in this study, a mix of perennial grasses and alfalfa) [31]. Also, biological nitrogen fixation, beneficial mycorrhizal associations, fungal endophytes [104], and other lesser understood symbiotic relationships, offer potential to further increase food and biomass production, with the potential for reduced inputs of fertilizers and other chemicals [105-107]. These mutually beneficial associations, which generally enhance the fitness of the host plant, will likely be of particular importance on marginal soils where access to necessary minerals and water may be limiting.

Cereal crops including wheat, rice, and corn provide approximately half of the human diet in terms of calories and an even higher percent when accounting for livestock and poultry feed [108]. Thus, it is obvious that annual crops will remain a major component in human diets (directly or indirectly) for generations to come and that research must continue toward increasing crop yields, sustainability [109], and nutrition, especially in developing countries [110]. It is by no means suggested here that perennial crops would fully replace such enduring and necessary agricultural staples. However, with the exception of maize in some regions of the world, rates of yield increase of annual crops are reported to be declining [108]. The situation for cereals in general is shown in Figure 1.

Thus, current production barriers will have to be broken to continue to feed the additional 80 million people being added to the world annually. Additionally, as mentioned above, the desire and need to diversify human diets with more nutritious foods, including nuts and fruits high in micronutrients and phyto-nutraceuticals, is growing in importance. The benefits of a plentiful, nutritious diet should not be underestimated in the battle against poverty [111]. In this capacity, perennial crops can play a vital role in diversifying human nutrition while supporting an ever-increasing world food demand.

Utilizing plant genetic diversity has been an important component of previous production improvements [112]. Inter- and intra-species genetic diversity will be even more important for future increases and enhancements to the world food supply. Furthermore, while long-term future goals should include the development of improved, perennial replacements for annual crops grown on our tillable land, it must be stressed that their most immediate and attainable role will be in reclaiming and improving steep and/or degraded lands not suitable for the cultivation of annuals. We believe this approach is especially critical when expanding production of bioenergy crops. It is imperative to avoid competition between food and energy crops on lands traditionally used for food production, as the competition raises food prices, which particularly impacts the world's poor while increasing the pressure to crop marginal lands unsustainably and with improper species.

It may be acceptable that yields of food or biomass produced on degraded, marginal, or sloping lands be less per hectare than those of annual crops produced on level fertile farmland. Degraded lands would otherwise produce very low (or no) yields of food, timber or energy crops, or their lifespan for useful production would be limited, such as when fragile tropical soils are deforested and planted to soybeans and other annuals, as is occurring in the Amazon and other rain forest areas. Planting degraded lands to an appropriate mix of improved perennial species would provide an opportunity to harvest a supplemental food or energy product while preserving, building, and enhancing the soil. Improving the soil will promote increased yields over time, as demonstrated by work done in Africa [91,113], especially when the land is replanted to more advanced cultivars after some years. Developing 
complementary technologies to utilize charcoal and other organic wastes, much like the early inhabitants of the Amazon Basin, may not only enhance our ability to increase both food and biomass production but may also allow us to sequester the harvested carbon for millennia [114,115].

Research along these lines has been in progress since the 1970s [116-118]. Pimentel et al. have provided a useful early review and proposal [119]. Early work on perennial wheatgrass (Thinopyrum intermedium) began in the former Soviet Union in the 1920s and in the 1920s and 1930s at the U.S. Department of Agriculture [120-122] but was later abandoned. Considerably more recent work has been done, for example, on perennial wheat (Triticum sp.) [117,118,122], including an economic analysis of a mixed dryland system in Australia that included livestock [123]. Other grains in mixedand monocultures have been examined by Piper [124]. Strong arguments for perennial grain development have been presented by several authors [15,125-128].

Jackson and co-workers at the Land Institute in Salina, Kansas, USA have been examining and enhancing the potential of perennial grains, legumes, and other forbs adapted to prairie regions for a more sustainable replacement of annual crops. They have initiated breeding programs for a number of species, including perennial wheat, rye (Secale sp.), sorghum (Sorghum sp.), and others [29,95,96,98]. Jackson's concepts, referred to as Natural Systems Agriculture [129], include the development of an agricultural system that relies on the ecological benefits of diverse natural ecosystems, with the long-term aim of little or no sacrifice in food production. Jackson's approach was derived from observations of highly productive and self-sustaining native prairies, which consist of a diverse mixture of perennial species predominated by warm and cool season grasses, legumes, and composites. Land Institute plant breeders have been working to improve select species within these four groups to ultimately develop ecologically stable, sustainable, low-input perennial polycultures [95]. The promise and sustainable nature of these systems, especially in terms of low-input biomass production, is well supported by research findings of Tilman et al. [68,130,131] and Glover et al. [100].

Jackson's group is working to increase the seed size and yield of perennial grains, legumes, and other species, many of which naturally express shattering seed and other negative traits that will require improvement through an ambitious and long-term systematic breeding program [96]. These perennial crops if grown on presently tilled land must ultimately produce similar or greater yields per hectare than their annual counterparts to be widely accepted by farmers, which makes their development and final implementation very challenging. Importantly, this is not as much the case with all perennial species, as numerous, widely adapted nut, oil-crop, and fruit species exist in their native state that already produce good yields of high-quality, nutritious, accessible, and marketable products [94,132]. As discussed earlier, tree crops for marginal and sloping lands need not be required to produce equivalent or greater yields per hectare than annuals on level farmland. This actuality, in addition to their environmental benefits, may lead to faster development, acceptance, and widespread implementation of improved tree crops, despite longer generation times for breeding.

It is outside the scope of this review to provide a comprehensive list of appropriate species and breeding objectives. However, a selection of species is discussed here as examples that show the potential for substantial improvement and expanded use, and from which a framework can be built upon to develop and enhance other lesser-known species. 


\section{Nut Trees for Human Food and Animal Feed}

We envision, as did J. Russell Smith, that the improvement and widespread production of nut tree crops can play a major role in expanding the world's sustainable food production capacity. Nut trees are, in general, widely adapted, long-lived perennials that are well suited for agroforestry production systems [133], sloping and rocky land, and marginal soils. Examples of productive and sustainable nut production on sloping land include the chestnut forests of Italy and Corsica [8], hazelnuts on the hills adjacent to the Black Sea in northern Turkey [134], and the native walnut-fruit forests of southern Kyrgyzstan and other mountainous regions of Central Asia [135]. Besides the nut crop itself, which can serve as supplemental animal and/or human food, many of these species also produce valuable timber, shade, and beauty. Furthermore, clinical and epidemiological research has provided strong evidence that frequent consumption of tree nuts is associated with lower risks of stroke, cancer, heart disease, inflammation, with better plasma lipid profiles as well as reduction in other chronic health problems [136].

The tree nut crops represent a group of highly useful, yet underutilized species, which for the most part have undergone little modern genetic improvement. This is in contrast to our annual cultivated crops, which have undergone thousands of years of selection under domestication and a century of advanced breeding. Yet, in their wild state, many nut species produce a high-quality and highly nutritious food considerably more useful than that produced from the wild progenitors of annual crops. For example, large quantities of pecans and essentially all black walnuts (Juglans nigra L.) are harvested from native stands in the U.S. [137,138]. Most trees grown in commercial orchards were not the result of controlled breeding efforts and largely consist of cultivars that were developed by identifying and propagating the best trees found in native forests, or selected seedlings of those trees. The few cultivars released from recent breeding programs are generally from first generation progenies $[139,140]$. This pattern is repeated for most nut species worldwide, as production orchards and trees in home gardens consist of seed propagated plants or grafted local selections largely derived from the wild. As a result, genetic diversity and opportunities for improvement remain very high. While the number of active nut tree breeding programs around the world is limited, and most have been operating for only the past few decades, substantial progress has been demonstrated, and the potential for rapid improvement in many species is great [13]. In addition to centers of commercial production, nut trees continue to be an important part of edible landscapes across wide regions of many countries. Vast opportunity exists to increase their use in this manner, especially in cities, suburbs, small towns and rural areas. In the following sub-sections, several nut tree species are discussed in more detail to provide their current status and emphasize their potential for improvement and much wider utilization.

\subsection{Juglans regia}

Persian (English) walnuts are native to a wide geographic area spanning from western China through the mountain ranges of Central Asia to the Caucasus and eastern Turkey. They have also become naturalized in eastern China, Western Europe, North Africa, and the U.S. [141]. This widely adapted species produces a flavorful, nutritious food that contains a high level of omega-3 fatty acids, as well as other phytochemicals associated with improved cardiovascular health [142,143]. Worldwide, China is the largest producer of walnuts (1,060,600 MT in 2010), followed by the U.S. (458,000 MT), 
Iran, Turkey, Ukraine, Romania, France, and India [9]. In the U.S., walnuts are primarily grown in California. They became an important crop in this state after introductions from France and Spain in the late 1800s and the subsequent selection and breeding of productive, better-adapted cultivars [144]. The later introduction of more cold-tolerant germplasm from the Carpathian Mountains of Poland expanded the areas where this crop can be grown in North America [145]. However, commercial production remains in California, since measurable improvements in cold hardiness, resistance to pests and diseases, leaf and flower phenology and other traits are required to increase the area where this species can be reliably and economically grown.

The genetic diversity exists to augment the commercial growing regions of Persian walnuts significantly [141]. Unfortunately, breeding and research efforts have primarily been limited to locations in mild climates with breeding objectives focused on the needs of existing commercial industries, such as the extensive walnut breeding program at the University of California, Davis [146].

Millions of Persian walnut trees currently grow in the mountain fruit forests of Central Asia as well as in parts of Eastern Europe, the Himalayas, and China [135,141,147,148]. Germplasm from these areas, especially in northern latitudes and at high elevations, holds great opportunities for improvement of the species, especially in terms of adaptation to new regions. Much of this extensive pool of genetic resources has been inaccessible for centuries, as trees are located in remote and mountainous terrain in sometimes politically unstable and/or isolated regions. As a result, Western breeding efforts have had limited access to the center of diversity of the species, where traits such as fruit clusters with up to 20 nuts, precocious trees (flowering at one to two years from seed), dwarf trees, paper-thin shells, early maturity, secondary flowering with perfect flowers ( $J$. regia is typically monoecious), drought tolerance, cold-hardiness and disease resistance have been observed [147-149]. Obtaining, evaluating, and utilizing a diverse collection of this germplasm in a genetic improvement program, supported by recent advances in walnut genetics, breeding, and biotechnology [143,146,150-152], would allow for the development of new cultivars productive in most temperate and semi-arid regions of the world.

Persian walnut germplasm from Central Asia has been introduced recently to the U.S., including collections from Uzbekistan, Kyrgyzstan, Tajikistan, and other locations underrepresented in Western holdings [144,153]. These collections exist at the USDA ARS Clonal Germplasm Repository in Davis, California, with more recent and substantial introductions held at Rutgers University in New Jersey and in Utah and Idaho under the direction of the research organization Improving Perennial Plants for Food and Bioenergy (IPPFBE). Systematic evaluations of these new introductions for traits important to wider adaptation and improved production capacity are currently underway.

The average yield of Persian walnuts in the U.S. in 2004 was 1.45 metric $t$ of shelled nuts per hectare [154]. From $1.45 \mathrm{t}$ of nutmeat one obtains $9.48 \times 10^{6}$ cal consisting of $15.2 \%$ high quality protein, $65.2 \%$ high quality fat, $13.7 \%$ carbohydrates, $1.1 \%$ minerals and $4.1 \%$ water [141]. Walnuts are also one of the best plant sources of health-promoting omega-3 fatty acids [155]. For an average diet of $2000 \mathrm{cal}$, if $10 \%$ of the diet were to come from walnuts, then one hectare at $9.48 \times 10^{6} \mathrm{cal} / \mathrm{ha} / 200 \mathrm{cal} /$ person $=47,400$ people obtaining $10 \%$ of their dietary needs from one hectare of walnuts alone. When extended to greater land area and to other crops, the possibility of supplying significant parts of the diet for large numbers of people becomes evident. Ten percent is an arbitrary figure used simply to indicate what is possible. Food security comes not from having one or a 
few sources of nourishment but from a multiplicity, especially in the face or rising prices and growing climatic instability.

\subsection{Juglans nigra}

Eastern black walnut is a widely adapted, productive tree native to much of eastern North America [156]. Its richly flavored, thick-shelled nuts were a prized food of Native Americans and colonists, and are a staple for wildlife, especially squirrels (Sciuridae spp.). Black walnut kernels continue to be in high demand for baked goods, ice cream, and candies, with demand generally exceeding supply, despite a higher price than many other nuts [143]. The Hammons Products Company of Stockton, MO, bought and shelled an average of 30 million pounds (13.6 million $\mathrm{kg}$ ) of black walnuts each year from 2007 to 2009 (Prindle J, Personal Communication) [157]. The nuts were mostly gathered by hand from wild trees. Wood from black walnut trees continues to be sought for furniture, veneer, and gunstocks. As they become less available, timber buyers eagerly seek the best trees, with a record $\$ 30,000$ paid for one tree in 1976 [158]. Furthermore, black walnut shells after removal of kernels are ground to provide a material with a very high modulus of elasticity (resistance to deformation). This product is used in many industrial applications including cleaning jet engines, maintaining seals in oil well drilling, and plaster-effect paints [158].

A great deal of genetic diversity exists across wild black walnut populations in the eastern and Midwestern U.S. [159]. Past breeding efforts spanning several decades have been focused primarily on improving timber qualities of the trees, such as apical dominance, rapid growth, and a higher percentage of heartwood, with nut production of only limited consideration [160,161]. Fortunately, superior trees have been selected from forests with improved nut characteristics, such as high kernel percentage, thinner shells, and easy kernel extraction that form the basis for limited commercial production and for breeding trees with improved nut quality. For example, select cultivars and seedling selections exist that have thin shells and a kernel percent up to $34 \%$, whereas nuts of wild plants average only $8 \%-10 \%$ kernel. Furthermore, select trees have been identified that produce nuts on short spurs (spur-fruiting), as opposed to production on terminal branches, which is believed to increase yield potential and precocity of trees expressing this characteristic [12,162,163].

Only very recently have breeding efforts been initiated to combine improved nut traits and other important characteristics, such as resistance to walnut anthracnose (Gnomonia leptostyla [Fr.] Ces \& de Not.) into advanced generation hybrids. As such, and as described above for Persian walnuts, substantial opportunities remain to make further improvements in most characteristics, including adaptation to various locations, yield, disease and pest resistance, and kernel percent and quality $[137,164]$. Cycles of population improvement, including phenotypic and genotypic recurrent selection and population backcrossing, should further enhance useful characteristics and provide opportunities to utilize black walnut on a much larger scale with more consistent high-yields and improved quality, the lack of which are major drawbacks to the current dependence on crops from the wild [162,164,165]. Black walnut germplasm collection, evaluation, and breeding for improved nut production, yield, kernel quality, and tree health is underway at the University of Missouri Agroforestry Center in New Franklin, Missouri. Additional research and breeding has also been initiated at IPPFBE with a focus on improved nut production but with the major primary objective of selecting plants adapted to the harsh environment of the Intermountain West region of the U.S. [153]. Research and breeding of black 
walnut for timber is centered at the Purdue University Hardwood Tree Improvement and Regeneration Center in West Lafayette Indiana. Also, numerous private collections of black walnut cultivars and seedlings are held by members of the Northern Nut Growers Association [166], some of which include private improvement efforts [167,168]. Susceptibility to the newly discovered thousand cankers disease of black walnut has been studied across a number of species with the ultimate aim of finding genes for resistance. The disease is complex in that it involves both an insect, the walnut twig beetle, Pityophthorus juglandis, and a fungal pathogen Geosmithia morbida [169].

\subsection{Carya spp.}

Pecan is the most economically important nut species native to North America. It can be found growing throughout the south-central U.S. including Mississippi, Louisiana, Texas, Oklahoma and Arkansas, and north into parts of Kansas, Missouri, Tennessee, Kentucky, Illinois, and Iowa. It is also native to Mexico, where isolated populations can be found as far south as Oaxaca [140,170]. Native stands along the Mississippi river and its tributaries furnished tasty, nutritious nuts and excellent timber to Native Americans, early explorers, and colonists, along with being a staple for wildlife. Many native groves continue to be harvested both for nuts and timber. Selections of superior trees from the wild, as well as chance seedlings and recent cultivars from controlled breeding efforts have allowed commercial pecan production to spread throughout the southeastern U.S. and westward to Arizona, New Mexico, and parts of Utah and northern Mexico [140,170]. Pecan production is now also present to varying degrees in China, Israel, Brazil, South Africa, Egypt, Australia, Argentina and Peru $[140,171]$. The long growing season required for pecan nuts to mature coupled with its relatively late spring blooming characteristics are the major limiting factors to expanding the range of production into colder regions.

Wild pecans from their most northern range in Iowa, however, which are adapted to shorter growing seasons, have been collected and evaluated with superior individuals selected. While these northern trees typically have small-size nuts, they are of high quality and produce consistently in southern Canada near Niagara Falls [168]. It may possible that superior northern trees could be used in breeding efforts, when hybridized with southern genotypes that produce larger nuts, to produce offspring able to mature commercial-quality nuts in shorter growing seasons. Another promising approach to enhance the adaptation of pecan may be through interspecific hybridization with other Carya species, including shagbark hickory (C. ovata [Mill.] C. Koch), shellbark hickory (C. laciniosa [F. Michx.] Loudon), and bitternut hickory (C. cordiformis [Wangh.] C. Koch), of which natural hybrids already exist [140,172].

The hickories represent a group of nut trees that have undergone essentially no genetic improvement. Existing cultivars have been selected from the wild by amateur horticulturalists and members of the Northern Nut Growers Association [172]. In general, they are attractive, widely adapted, and cold-tolerant trees that produce excellent timber and delicious but thick-shelled nuts that can mature in a short growing season. Superior trees of shagbark and shellbark hickory have been identified that produce large nuts with thin-shells, excellent flavor, high-kernel percent, and the ability to crack out in halves - most wild hickories have small kernels that are difficult to extract. Existing pecan-hickory hybrids can form the basis of an interspecific genetic improvement (modified backcross) program to combine the thin-shell and high kernel percent of the pecan with the cold 
hardiness, wide-adaptation, earlier bloom and short growing season of hickory $[140,172]$. Some of the problems of such an approach have been discussed by Potts and Dungey with respect to eucalyptus [173].

Currently, the only significant pecan breeding program in the world is conducted by the USDA ARS Pecan Breeding Program in Brownsville, Texas, where efforts are focused on developing improved, disease-resistant, high-quality pecan cultivars for the current production regions. The wide genetic diversity found in pecan and other Carya species offer considerable long-term opportunities to significantly expand the usefulness of the genus for food and timber production across temperate and sub-tropical parts of the world [174].

\subsection{Corylus spp.}

The commercial production of hazelnut, Corylus avellana L., is currently limited to areas of the temperate world bordering large bodies of water that have mild, wet winters and cool summers, such as the Mediterranean Sea coasts of Italy and Spain and the Black Sea coast in Turkey [134]. Turkey generally produces around $70 \%$ to $80 \%$ of the world's crop, Italy produces around $17 \%$, and the U.S. and Spain, which each produce less than 5\% [9]. Commercial production in the U.S. is limited to the Willamette Valley of Oregon. Current areas of hazelnut production do not represent the wide native range of C. avellana, as it is found throughout most of Europe as far north as $61^{\circ} \mathrm{N}$ in Finland and $68^{\circ} \mathrm{N}$ in Norway and eastward through St. Petersburg to $58^{\circ} \mathrm{N}$ in the Ural Mountains, and south to the Caucasus, and Asia Minor [175]. Nearly all cultivars grown commercially were derived from plants selected from the wild with the breeding of improved hazelnuts only a relatively recent activity. As such, a great diversity of $C$. avellana genetic resources exists in germplasm collections and in the wild, further enhanced by their out-crossing, self-incompatible nature. In addition, the wild species C. americana Marshall in North America and C. heterophylla Fisch. in Asia are adapted to colder and more stressful climates, although they generally produce small, thick-shelled nuts. They can be hybridized readily with $C$. avellana and could be utilized to develop advanced generation offspring that express the most favorable traits of both species [175-177]. A number of first generation C. americana $\times$ C. avellana hybrids are currently available from the USDA ARS National Clonal Germplasm Repository in Corvallis, OR, which are the result of breeding work initiated in the early 1900s [178].

Production of $C$. avellana in the eastern U.S., which has been attempted since colonial times, has been limited due to eastern filbert blight (EFB), a native disease caused by the fungus Anisogramma anomala (Peck) E. Müller [134,179]. Eastern filbert blight, harbored by the tolerant $C$. americana, can be found across much of the U.S. and southern Canada, east of the Rocky Mountains, and since the late 1960s also in the Willamette Valley where it was previously absent. Breakthroughs in identifying C. avellana germplasm resistant to this disease at Oregon State University (OSU) and more recently Rutgers University have provided genetic resources to largely overcome this major impediment to production [134,180-184]. Using this resistant germplasm, very significant progress has been made in the past decade to develop European hazelnuts that can be grown successfully across a much wider region.

Replicated yield trials of promising new EFB-resistant cultivars and experimental selections are currently being established across the Mid-Atlantic region and southern Ontario where the climate is amenable for immediate production. To develop hazelnuts that can be produced in the more harsh 
environments of the Midwest and upper Midwest regions of the U.S., a collaborative research effort has been established between OSU, Rutgers, the National Arbor Day Foundation, and the Nebraska Forest Service (in association with the University of Nebraska, Lincoln). The goals of this collaboration are to develop cold-hardy, drought-tolerant, and EFB-resistant plants by hybridizing elite, but cold-sensitive $C$. avellana breeding selections developed at OSU with cold-hardy, EFB-resistant, high-yielding $C$. americana and $C$. americana $\times C$. avellana hybrids. Additional hazelnut research is currently ongoing at the University of Minnesota, the University of Wisconsin, and the University of Guelph (Ontario, Canada), as well as Badgersett Research Farm in Canton, Minnesota where private breeding efforts span more than 30 years.

The recent interest in hazelnuts in North America is due to the fact that they are a low-input, high-value crop with few insect and disease pests. Based on the wide genetic diversity and inter-fertility of the genus, their relatively short generation time (four to five years to maturity), and small plant size compared to other tree species, rapid breeding progress is being made [185,186]. Some results are shown in Table 1 for the old Spanish cultivar Casina to exemplify the potential of hazelnuts. To be sure, "Casina" has a relatively high kernel to shell ratio (56\%) [187] as well as a high oil content (65\%) [188] compared to other hazelnut cultivars, and it is not resistant to eastern filbert blight (EFB), so it cannot yet be grown in the eastern United States. Great potential exists when working with an underutilized perennial crop that has undergone almost no breeding, including the exploitation of interspecific hybridization for significant improvements in adaptation, yield, disease resistance, and vigor. Similar outcomes can be expected with the other temperate nut tree crops mentioned above, as well as a number of additional species that also merit attention, such as pistachios (Pistacia spp.), chestnuts, heartnuts (Juglans ailantifolia var. cordiformis [Maxim] Rehd.), oaks (Quercus spp.), and many others.

Table 1. Kernel and oil yield, 10 year comparison, 1996-2005 [9,187,188].

\begin{tabular}{ccc}
\hline Item & Soy Bean & Hazelnut (Casina) \\
\hline Average kernel yield (kg/ha) & 2601.4 & 1379.2 \\
Oil (\%) & 19 & 65 \\
Oil yield (kg/ha) & 494.3 & 896.5 \\
Oil ratio Hazelnut: Soy & & 1.8 \\
\hline
\end{tabular}

\section{Food and Bioenergy Tree Crops in Warmer Climates}

During his travels and studies, J. Russell Smith recognized the need to further develop and utilize tree crops in the degraded rainforests of the tropics. He witnessed the great genetic diversity and potential of tropical plants, the fragile soils, and the vital role tree crops and legumes play in preserving and maintaining these areas. In his book he mentions the genetic improvement of rubber (Hevea brasiliensis [Willd. ex A. Juss.] Müll. Arg.), oil palm, Cinchona spp., and other tropical tree crops by Dutch breeders in Java prior to World War II. Expanding on this topic, there are hundreds of useful, unimproved perennial crops that have the potential to be much more widely used for food, fiber, timber, bioenergy, and soil improvement. The longer growing season, enormous areas with ample rainfall, and greater light intensity in this region enables exceptionally high yields from many species. Some examples of relatively common crops with the potential for much further 
improvement and wider use include coconut (Cocos nucifera L.), date palm (Phoenix dactylifera L.), Brazil nut (Bertholletia excelsa Humb. \& Bonpl.), cashew (Anacardium occidentale L.), oil palm, mango (Mangifera spp.), macadamia nut (Macadamia spp.), cacao (Theobroma cacao L.), avocado (Persea americana Mill.), papaya (Carica papaya L.), candlenut (Aleurites moluccana [L.] Willd.), and ivory nut (Phytelephas aequatorialis Spruce). In addition, there are also many lesser known species, referred to as orphan or Cinderella crops, with great potential [189,190]. It should also be noted, that while much knowledge has been gained on tropical perennial crops in recent years, a gap in the translation of this knowledge to growers (including the use of advanced plant materials) is widely apparent and much improvement is needed on this front. Coconut, well-known and widely grown crop, is an example of the need. It is planted on around 12 million hectares worldwide, with more than $90 \%$ of the production managed by individuals farming four or fewer hectares. Most coconut plants in production are cultivars chosen by farmers from local tree populations. They are not advanced selections from modern breeding programs. As a consequence, the average world yield is between 0.3 and 1.5 MT ha ${ }^{-1}$ of copra, the dried kernel from which oil is extracted, whereas yields of 4.0 to 6.0 $\mathrm{MT} \mathrm{ha}^{-1}$ are common with new cultivars developed by existing breeding programs $[191,192]$.

Bolstering work on tropical perennial crops would increase local food and energy security and support options for small farmers to produce a variety of profitable and nutritious crops. It would also help to retain genetic diversity on the species and ecosystem levels, as many lesser-known crops are only harvested from the wild, and they are becoming less available due to deforestation and changes in land use $[79,80,91,193]$.

Through continual cycles of breeding and selection, a number of perennial species should have the capacity to produce equivalent or higher yields of food and/or biomass than many annual crops, as illustrated by oil palm (Elaeis spp.), sugarcane (Saccharum spp.), and hybrid eucalyptus (Eucalyptus spp.). Oil palm provides a noteworthy example of crop and biomass productivity, as the best plantations in Indonesia yield $7.5 \mathrm{t}$ of oil in addition to 20-30 $\mathrm{t}$ (dry weight) of plant biomass per hectare per year [72]. The recent significant rise in oil palm production is currently under debate due to its ability to affect biodiversity in tropical regions when planted in monocultures [74]. It is used as an example in this review purely to demonstrate how productive an existing perennial crop can be compared to annuals, despite undergoing only a limited amount of genetic improvement. The criticism also provides support for why a need exists to develop local/regional research centers focused on developing multicrop, mixed perennial agriculture. To be successful, it is vital to develop the most appropriate methods to utilize perennial crops, while enhancing biodiversity and ecosystem health, such as that discussed by Gorchov [76] and Laurance et al. [75], in the case of oil palm. Additional genetic improvement is demonstrated by yields of up to $12 \mathrm{t}$ of oil per hectare per year in current breeding nurseries, with a theoretical yield of $18 \mathrm{t}$ of oil per hectare [97,192]. When considering the oil, which is edible, oil palm plantations can produce more food calories per hectare per year than are obtained from many currently cultivated annual species [61,74,154,172,173].

Since most tropical species have undergone few cycles of genetic improvement, if any, they retain considerable genetic variation, and rapid genetic gains can be expected. Population improvement programs can produce high-yielding, enhanced cultivars with desired levels of genetic diversity for immediate use, superior sources for new clonal selections, and the foundation for additional cycles of genetic improvements. Interspecific hybridization will enable the incorporation of many useful traits, 
adding to genetic diversity. The development of efficient clonal propagation techniques, including micro-propagation, permits the immediate exploitation of hybrid vigor [193].

A striking example of genetic improvement in a perennial tropical species has been demonstrated in rubber (Hevea brasiliensis Müll.Arg.). First generation clonal tests led to the identification of individual plants that doubled the latex yield of earlier selections. Subsequent intercrosses of the best clones produced a further doubling of yield. With additional breeding, these high yields were combined with pest resistance and other desirable traits [94]. Also providing a striking example, new cultivars of macadamia nuts, a very recently domesticated species, produce four times the yields of earlier clones [94].

Several multi-purpose tropical tree crops also deserve mention as they are quickly increasing in world importance and great opportunities exist to increase their usefulness for many applications through breeding. Dramatic progress has been and continues to be made in the genus Leucaena, a premier nitrogen-fixing, multipurpose forage, soil-reclamation, and fuel-wood tree, with rapidly growing, high-quality, pest-resistant clones now in commercial production [194,195]. Substantial improvement with only limited breeding efforts has also been demonstrated in Acacia spp., a large genus of fast-growing, multi-purpose leguminous trees and shrubs that are adapted to arid environments and infertile, degraded, and acidic soils [196,197].

Excellent progress is also being made in the improvement and culture of various species and hybrids of Eucalyptus [198]. Plants of this genus are used for producing pulp for paper, as well as firewood, charcoal, shade, windbreaks, furniture, fiber board, plywood, volatile oils, and cleaning products [199]. Since 1950, pulp and paper companies in the Atlantic coastal states of Brazil have increased Eucalyptus spp. yields from $20 \mathrm{~m}^{3}$ of pulpwood per hectare per year to current yields of more than $40 \mathrm{~m}^{3}$ per year, in seven-year rotations. This increase has provided Brazilian companies a considerable advantage in production costs of pulp, paper, timber, charcoal for steel production, and biofuels [199]. Even with these increases in biomass yield, the breeding potential of Eucalyptus is still considered underutilized. Screening programs of large numbers of hybrids produced increases in yield of $200 \%$ and enabled selection for 15 other valuable traits [94]. Exceedingly high growth rates of 70-90 $\mathrm{m}^{3}$ per hectare per year have been observed in small plots in east and west Africa, Brazil and Papua New Guinea [198], demonstrating the even greater production potential of the genus. Care will have to be taken, though, to avoid the well known environmental problems which can arise with this crop.

Eucalyptus uses large amounts of water and can drain water resources from surrounding areas [200,201], thereby jeopardizing crops grown nearby. Its best plantation yields require considerable fertilizer inputs [201]. Jawit et al. have described such problems in Thailand as well as some options for alleviating them [202,203]. Many of the ecological challenges associated with sustainable plantation management as well as helpful approaches have been discussed by Liu and Li [204] and by Binkley and Stape [205]. Ultimately sustainable cultivation, however, will probably require altering the monocrop model. Alteration has been shown to work with respect to pest management in eucalyptus plantations in Brazil, where coexistence of eucalyptus with native vegetation reduces Lepidoptera infestation [206]. It is only a short step from there to introduce other potentially useful species along with the preexisting native vegetation, leading to a more sustainable mixed culture. Such a model could potentially be developed for most monocultures. 
It has been suggested that tropical forests can sequester or store 1.5 to 2.5 times as much carbon as forests in the middle and high latitudes [207]. Many tropical forests, however, are being destroyed by illegal logging and burning by impoverished people needing employment and other resources to care for their families. In addition, many pristine rainforests have been and continue to be destroyed, cut for lumber and for cattle pastures and to be planted to soybeans. This use typically offers minimal employment, destroys the fragile soils, reduces infiltration of water and recycling of rainfall, greatly reduces biodiversity, emits large amounts of greenhouse gases, and eliminates the many other benefits and services provided by rainforests [208]. The importance and potential in these regions of the world to sequester carbon from the atmosphere cannot be over emphasized.

The FAO Global Forest Research Assessment update for 2005 estimates that degraded and secondary forests in tropical Africa, South America, and Asia covered 850 million hectares in 2002. The Partnership on Forest Landscape Restoration rejects the insistence that these modified forests be restored to their original pristine state. It recognizes that improving the flow of forest goods and services requires balancing livelihoods with protecting nature and that this approach is best achieved within dynamic multifunctional landscapes [209]. These large areas of tropical forests that have been or are being destroyed and planted to non-sustainable crops should be replanted to a diverse mixture of high-value tree crops and other perennial species for food, timber, and biomass production. In some locations this may take sizable investments in terms of soil rebuilding using appropriate legumes and grasses and/or amendments, as well as improved tree crops adapted to these new conditions. A strikingly successful mixed system for the rehabilitation of degraded cattle ranching lands involves integrating trees, shrubs, and grasses with grazing [210,211]. It is a sustainable, intensive silvopastoral system that supplies milk and meat as well as forestry products, while enhancing biodiversity.

Elsewhere we have discussed in some detail the necessity of accompanying breeding work with extensive economic, sociological, and cultural analysis and for the involvement of local farmers in research planning and conduct. Without the integration of these disciplines and people, research and extension programs are likely to founder [212].

\section{The Proposal}

An insightful principle that can be applied from Jackson's Natural Systems Agriculture concept is that regional agricultural systems should mimic their naturally occurring, self-sustaining ecosystems. As Jackson is working to develop perennial polycultures to replace annual crops in the prairie region of the U.S., this idea should be expanded and applied to diverse ecosystems worldwide. To fully exploit the huge untapped potential of perennial crops, the authors envision the development of a series of strategically located agricultural research stations around the world designed for the long-term intensive genetic improvement, development, and implementation of perennial food, timber, and bioenergy crops for land reclamation, reforestation, and production on marginal lands. These focused research stations should be developed in China, South Asia, Japan, Australia, Central Asia, Europe, Africa, the Middle East, South America, and North America-a significant expansion of J. Russell Smith's U.S. based "Institutes of Mountain Agriculture" [8]. These stations could be associated with already existing institutions, such as universities or research institutes, or be newly created research facilities. One can only imagine the potential towards this goal of revitalizing and reorienting the numerous N.I. Vavilov Research Institutes of Plant Industry (VIR) spanning the former 
Soviet Union. These proposed stations would have several related objectives, the first of which would be identifying the most promising perennial food, bioenergy, and timber species for each region (based on climate, soil, topography, culture, economics, and other factors). They would also develop effective and efficient programs in long-term genetic improvement and other research (production technologies, propagation, etc.) to enhance the most promising species. Thirdly, they would implement (through education, outreach, and cooperation at the local level) their use in a sustainable, economical, and environmentally friendly fashion. Part of this work would be ensuring that superior cultivars and knowledge already existing are made available and put into wide use by civilization.

\section{Conclusions}

This review builds upon and supports J. Russell Smith's concepts of perennial crop agriculture. If his vision had been developed and expanded beginning in 1929, or even in the 1950s when a revision of his text was released, the world would have greater options to address the related and growing problems of food and energy security and environmental degradation. Nevertheless, tremendous biological and agricultural knowledge has been accumulated during the past century, highlighted by the remarkable success in improving yields of annual cereal crops, sparking the Green Revolution. This body of knowledge, combined with advances in molecular biology and other fields, provides highly tangible support for the approach described herein. Furthermore, the end of the Cold War allows much greater access to germplasm resources that were previously inaccessible to Western breeders. The focused utilization of these resources could allow for the development and subsequent planting of billions of improved trees and other perennial plants for food, fiber, timber, bioenergy and land restoration worldwide.

Implementing the approach described here on a large scale would revitalize agriculture throughout the world, ensure improved incomes for producers, and rejuvenate agricultural research, education, and extension, along with numerous supporting sciences, as well as industrial applications. However, research must be done in combination with education and outreach to the many small landholders, farmers, and workers, especially in the developing world. In addition, there must be certification systems developed to verify the use of sustainable and ecologically responsible practices. This great challenge will require a multidisciplinary approach including input from soil scientists, plant breeders, agronomists, ecologists, plant physiologists and pathologists, anthropologists, educators, economists, cultural specialists, environmentalists, NGOs, and governments.

To have the greatest positive impact, perennial food, timber, and biofuel crops must be produced according to best known management practices using standards and, as mentioned above, certification procedures similar to those now spreading throughout the world's timber industries [213]. Standards and certification procedures are also being developed for the oil palm industry [214]. However, these initiatives are not without their flaws at present, and improvements are needed [156]. Developing appropriate certification would help ensure sustainable, long-term productivity and environmental enhancement, while also reducing exploitation of human labor. Monetary investments in agricultural research historically yield high rates of return. The World Development Report of 2008, Agriculture for Development compiled by the World Bank, reports that agricultural research has provided an average rate of return of $43 \%$ in the 700 development projects evaluated [215]. The rate of return on research and improvement of perennial plants could be significantly higher based on the limited work 
that has been done previously and the expected early gains in the underutilized lands of the world as non-productive soils become fruitful [216].

It is clear that a multitude of efforts and approaches will be necessary to enhance future food and energy security. Without addressing these problems in the near future, the combination of a rapidly growing population, declining per-capita food production capacity, and the uncertainty of climate change will diminish the quality of life of millions, if not billions, of people. Now is the time to consider exploring and implementing J. Russell Smith's concepts in a dramatic and substantial way, including development of his agricultural institutes. Future generations may not have the resources, time, peaceful existence, or state of mind necessary to allow for long term investments in sustainability and quality of life. Smith's Tree Crops concepts, if expanded and implemented, may indeed provide a valuable tool to develop a more permanent agriculture, leading to a prosperous and sustainable bio-economy.

\section{Acknowledgments}

The authors would like to acknowledge support from the New Jersey Agricultural Experiment Station, the Rutgers Center for Turfgrass Science, and Improving Perennial Plants for Food and Bioenergy, Inc. PCK acknowledges anonymous private support. We also thank J. Capik, C. Leadbetter, D. Zaurov, J. Heckman, J. White, B. Clarke, G. Zhang and S. Baxer for their contributions to this work.

\section{Conflicts of Interest}

The authors declare no conflict of interest.

\section{References and Notes}

1. Gill, V.; Dale, T. Topsoil and Civilization; University of Oklahoma Press: Norman, OK, USA, 1974.

2. Perlin, J. A Forest Journey, the Role of Wood in the Development of a Civilization; Harvard University Press: Cambridge, MA, USA, 1989.

3. Hillel, D. Out of the Earth-Civilization and the Life of the Soil; University of California Press: Berkeley, CA, USA, 1991.

4. Evans, L.T. Feeding the Ten Billion-Plants and Population Growth; Cambridge University Press: Cambridge, UK, 1998.

5. Williams, M. Deforesting the Earth-From Prehistory to Global Crisis; University of Chicago Press: Chicago, IL, USA, 2003.

6. Lal, R. Soil carbon sequestration impacts on global climate change and food security. Science 2004, 304, 1623-1627.

7. Matson, P.A.; Parton, W.J.; Power, A.G.; Swift, M.J. Agricultural intensification and ecosystem properties. Science 1997, 277, 504-509.

8. Smith, J.R. Tree Crops: A Permanent Agriculture; Devin-Adair: New York, NY, USA, 1950.

9. Food and Agriculture Organization of the United Nations Web Page. Available online: http://faostat.fao.org (accessed on 27 March 2013).

10. About Us. United States Department of Agriculture. Available online: http:/www.ars.usda.gov/ AboutUs/AboutUs.htm?modecode=66-06-05-00 (accessed on 16 August 2013). 
11. Xu, Y.X.; Hanna, M.A. Evaluation of Nebraska hybrid hazelnuts: Nut/kernel characteristics, kernel proximate composition, and oil and protein properties. Ind. Crops Prod. 2010, 31, 84-91.

12. Reid, W.; Coggeshall, M.V.; Hunt, K.L. Black walnut cultivars for nut production. Annu. Rep. North. Nut Grow. Assoc. 2004, 95, 65-77.

13. Mehlenbacher, S.A. Progress and prospects in nut breeding. Acta Hortic. 2003, 622, 57-79.

14. Fruit \& Tree Nuts. United States Department of Agriculture. Available online: http://www.ers. usda.gov/topics/crops/fruit-tree-nuts/background.aspx\#.UeMQXKx4lgE (accessed on 26 May 2012).

15. MacDaniels, L.H.; Lieberman, A.S. Tree crops: A neglected source of food and forage from marginal lands. Bioscience 1979, 29, 173-175.

16. Brown, L.R.; Renner, M.; Halweil, B. Vital Signs 2000, the Environmental Trends That Are Shaping Our Future; Worldwatch Institute \& W. W. Norton \& Company: New York, NY, USA, 2000.

17. Rosenzweig, C.; Hillel, D. Climate Changes and the Global Harvest-Potential Impacts of the Greenhouse Effect on Agriculture; Oxford University Press: Oxford, UK, 1998.

18. Lal, R.; Griffin, M.; Apt, J.; Love, L.; Morgan, M.G. Managing soil carbon. Science 2004, 304, 393.

19. Meehl, G.A.; Washington, W.M.; Collins, W.D.; Arblaster, J.M.; Hu, A.; Buja, L.E.; Strand, W.G.; Teng, H. How much more global warming and sea level rise? Science 2005, 307, 1769-1772.

20. Cohen, J.E. Human population: The next half century. Science 2003, 302, 1172-1175.

21. Conway, G. The Doubly Green Revolution: Food for All in the Twenty-First Century; Cornell University Press: Ithaca, NY, USA, 1998.

22. Organization for Economic Co-operation and Development Food and Agriculture Organization of the United Nations. OECD-FAO Agricultural Outlook: 2006-2015. Available online: ftp://ftp.fao.org/docrep/fao/009/a0621e/a0621e00.pdf (accessed on 27 March 2013).

23. Pretty, J.N. Regenerating Agriculture-Policies and Practices for Sustainability and Self-Reliance; Joseph Henry Press: Washington, DC, USA, 1995.

24. Federoff, N.V.; Cohen, J.E. Plants and population: Is there time? Proc. Nat. Acad. Sci. USA 1999, 96, 5903-5907.

25. Tilman, D. Global environmental impacts of agricultural expansion: The need for sustainable and efficient practices. Proc. Nat. Acad. Sci. USA 1999, 96, 5995-6000.

26. Tilman, D.; Fargione, J.; Wolff, B.; D’Antonio, C.; Dobson, A.; Howarth, R.; Schindler, D.; Schlesinger, W.H.; Simberloff, D.; Swackhammer, D. Forecasting agriculturally driven global environmental change. Science 2001, 292, 281-284.

27. Tilman, D.; Cassman, K.G.; Matson, P.A.; Naylor, R.; Polasky, S. Agricultural sustainability and intensive production practices. Nature 2002, 418, 671-676.

28. Cassman, K.G.; Dobermann, A.; Walters, D.T.; Yang, H. Meeting cereal demand while protecting natural resources and improving environmental quality. Annu. Rev. Environ. Resour. 2003, 28, 315-358.

29. Glover, J.D. The necessity and possibility of perennial grain production systems. Renew. Agric. Food Syst. 2005, 20, 1-4.

30. Conway, G.R.; Pretty, J.N. Unwelcome Harvest-Agriculture and Pollution; Earthscan: London, UK, 1991. 
31. Randall, G.W.; Huggins, D.R.; Russelle, M.P.; Fuchs, D.J.; Nelson, W.W.; Anderson, J.L. Nitrate losses through subsurface tile drainage in conservation reserve program, alfalfa, and row crop systems. J. Environ. Qual. 1997, 26, 1240-1247.

32. Pimentel, D.; Harvey, C.; Resosudarmo, P.; Sinclair, K.; Kurz, D.; McNair, M.; Crist, S.; Shpritz, L.; Saffouri, R.; Blair, R. Environmental and economic costs of soil erosion and conservation benefits. Science 1995, 267, 1117-1123.

33. Pimentel, D.; Houser, J.; Preiss, E.; White, O.; Fang, H.; Mesnick, L.; Barsky, T.; Tariche, S.; Schreck, J.; Alpert, S. Water resources: Agriculture, the environment, and society. Bioscience 1997, 47, 97-106.

34. Postel, S.L. Pillar of Sand: Can the Irrigation Miracle Last? W. W. Norton \& Company: New York, NY, USA, 1999.

35. Randall, G.W.; Mulla, D.J. Nitrate nitrogen in surface waters as influenced by climatic conditions and agricultural practices. J. Environ. Qual. 2001, 30, 337-344.

36. Foley, J.A.; DeFries, R.; Asner, G.P.; Barford, C.; Bonan, G.; Carpenter, S.R.; Chapin, F.S.; Coe, M.T.; Daily, G.C.; Gibbs, H.K.; et al. Global consequences of land use. Science 2005, 309, $570-574$.

37. Harlan, J.R. The Living Fields: Our Agricultural Heritage; Cambridge University Press: New York, NY, USA, 1998.

38. Stokstad, E. Deadly wheat fungus threatens world's breadbaskets. Science 2007, 315, 1786-1787.

39. Pennisi, E. Armed and dangerous. Science 2010, 327, 804-805.

40. Deffeyes, K.S. Hubbert's Peak-The Impending World Oil Shortage; Princeton University Press: Princeton, NJ, USA, 2003.

41. Deffeyes, K.S. Beyond Oil: The View from Hubbert's Peak; Macmillan: London, UK, 2006.

42. Hall, D.O.; Mynick, H.E.; Williams, R.H. Cooling the greenhouse with bioenergy. Nature 1991, $353,11-12$.

43. Hall, D.O.; Scrase, J.I. Will biomass be the environmentally friendly fuel of the future? Biomass Bioenerg. 1998, 15, 357-637.

44. Sims, R.E.H. Climate Change Solutions from Biomass, Bioenergy, and Biomaterials. Available online: http://www.ecommons.cornell.edu/bitstream/1813/10341/1/Invited\%20Overview\%20Ralph \%20Sims\%209Sept2003.pdf (accessed on 27 March 2013).

45. Pacala, S.; Socolow, R. Stabilization wedges: Solving the climate problem for the next 50 years with current technologies. Science 2004, 305, 968-972.

46. Perlack, R.D.; Wright, L.L.; Turhollow, A.F.; Graham, R.L.; Stokes, B.J.; Erbach, D.C. Biomass as Feedstock for a Bioenergy and Bioproducts Industry: The Technical Feasibility of a Billion-Ton Annual Supply; Oak Ridge National Laboratory: Oak Ridge, TN, USA, 2005.

47. Brown, L.R. Plan B: 2.0 Rescuing a Planet Under Stress and a Civilization in Trouble; W. W. Norton \& Company: New York, NY, USA, 2006.

48. Moreira, J.R. Global biomass energy potential. Mitig. Adapt. Strateg. Glob. Clim. Chang. 2006, 11, 313-341.

49. Ragauskas, A.J.; Williams, C.K.; Davison, B.H.; Britovsek, G.; Cairney, J.; Eckert, C.A.; Frederick, W.J., Jr.; Hallett, J.P.; Leak, D.J.; Liotta, C.L.; et al. The path forward for biofuels and biomaterials. Science 2006, 311, 484-489. 
50. Somerville, C. The billion-ton biofuels vision. Science 2006, 312, 1277.

51. Assadourian, E.; Bender, M.; Berner, C.; Carrus, K.; Chafe, Z.; Eckerle, K.; Flavin, C.; French, H.; Gardner, G.; Greer, L.; et al. Vital Signs 2006-2007; Worldwatch Institute \& W. W. Norton \& Company: New York, NY, USA, 2006; p. 23.

52. Brown, L.R.; Flavin, C.; Kane, H. Vital Signs 1996; Worldwatch Institute \& W. W. Norton \& Company: New York, NY, USA, 1996; p. 25.

53. Production of Cereals and Share in World. Available online: ftp://ext-ftp.fao.org/ES/Reserved/ essb/ess/ftp_essb/john\&Ozan/pdf/b01.pdf (accessed on 20 February 2012).

54. Crop Prospects and Food Situation. Food and Agriculture Organization of the United Nations. Available online: http://www.fao.org/docrep/009/J8104e/j8104e03.htm (accessed on 20 February 2012).

55. Richardson, S.D. Forests and Forestry in China; Island Press: Washington, DC, USA, 1990.

56. Zhang, P.; Shao, G.; Zhao, G.; Master, D.L.; Parker, G.R.; Dunning, J.B., Jr.; Li, Q. China's forestry policy for the 21st century. Science 2000, 288, 2135-2136.

57. State of the World Forests. Food and Agriculture Organization of the United Nations. Available online: http://www.fao.org/docrep/007/y5574e/y5574e00.htm (accessed on 27 March 2013).

58. An edible landscape can be defined as the use of various food-producing plants in the residential landscape in place of, or in combination with, more traditional ornamental landscape plants. Edible landscapes could combine adapted perennial fruit and nut trees, berry bushes, brambles and vines, vegetables, herbs, etc., along with other plants, into attractive and functional designs. Plantings provide abundant food and other related products of a diversity of types over the growing season, as well as shade and beauty. Edible landscapes are not a new concept in areas of the world that have undergone repeated food shortages. Several of the authors were greatly impressed by the diversity and density of edible plants found in the residential landscapes across much of Eastern Europe, southern Russia, and Central Asia, when travelling in these regions for germplasm collections and other research activities.

59. Cassman, K.G.; Harwood, R.R. The nature of agricultural systems: Food security and environmental balance. Food Policy 1995, 20, 439-454.

60. Green, R.E.; Cornell, S.J.; Scharlemann, J.P.W.; Balmford, A. Farming and the fate of wild nature. Science 2005, 307, 550-555.

61. Mukunda, H.S.; Dasappa, S.; Shrinivasa, U. Open-top wood gasifiers. In Renewable Energy Sources for Fuels and Electricity; Johansson, T.B., Burnham, L., Eds.; Island Press: Washington, DC, USA, 1993; pp. 699-728.

62. Williams, R.H.; Larson, E.D. Advanced gasification-based biomass power generation. In Renewable Energy Sources for Fuels and Electricity; Johansson, T.B., Burnham, L., Eds.; Island Press: Washington, DC, USA, 1993; pp. 729-785.

63. Bridgwater, A.V.; Meier, D.; Radlein, D. An overview of fast pyrolysis of biomass. Org. Geochem. 1999, 30, 1479-1493.

64. Chynoweth, D.P. Renewable biomethane from land and ocean energy crops and organic wastes. HortScience 2005, 40, 283-286.

65. Jackson, R.B.; Schlesinger, W.H. Curbing the U.S. carbon deficit. Proc. Nat. Acad. Sci. USA 2004, 101, 15827-15829. 
66. Hall, D.O.; Rosillo-Calle, R.; Williams, R.H.; Woods, J. Biomass for bioenergy: Supply prospects. In Renewable Energy Sources for Fuels and Electricity; Johansson, T.B., Burnham, L., Eds.; Island Press: Washington, DC, USA, 1993; pp. 592-651.

67. Hakkila, P.; Parikka, M. Fuel resources from the forest. In Bioenergy from Sustainable Energy; Richardson, J., Björheden, R., Hakkila, P., Lowe, A.T., Smith, C.T., Eds.; Kluwer Academic Publishers: Dordrecht, The Netherlands, 2002; pp. 19-48.

68. Tilman, D.J.; Hill, J.; Lehman, C. Carbon-negative biofuels from low-input high-diversity grassland biomass. Science 2006, 314, 1598-1600.

69. Curtis, F.; Ehrenfeld, D. The new geography of trade: Globalization's decline may stimulate local recovery. Solut. J. 2012, 3, 35-40.

70. Moreira, J.R. Sugarcane for energy-Recent results and progress in Brazil. Energy Sustain. Dev. 2000, 4, 43-54.

71. Basiron, Y. Palm oil production through sustainable plantations. Eur. J. Lipid Sci. Technol. 2007, 109, 289-295.

72. Corley, R.H.V. Oil palm: A major tropical crop. Burotrop Bull. 2003, 19, 5-8.

73. Danielsen, F.; Beukema, H.; Burgess, N.D.; Parish, F.; Brühl, C.A.; Donald, P.F.; Murdiyarso, D.; Phalan, B.; Reijnders, L.; Struebig, M.; et al. Biofuel plantations on forested lands: Double jeopardy for biodiversity and climate. Conserv. Biol. 2009, 23, 348-358.

74. Koh, L.P.; Wilcove, D.S. Oil palm: Disinformation enables deforestation. Trends Ecol. Evol. 2009, 24, 67-68.

75. Koh, L.P.; Wilcov, D.S. Is oil palm agriculture really destroying tropical biodiversity? Conserv. Lett. 2008, 1, 60-64.

76. $\quad$ Laurance, W.F.; Koh, L.P.; Butler, R.; Sodhi, N.S.; Bradshaw, C.J.A.; Neidel, J.D.; Consunji, H.; Mateo, V.J. Improving the performance of the roundtable on sustainable palm oil for nature conservation. Conserv. Biol. 2010, 24, 377-381.

77. Bhagwat, S.A.; Willis, K.J. Agroforestry as a solution to the oil palm debate. Conserv. Biol. 2008, 22, 1368-1369.

78. Stone, R. Can palm oil plantations come clean? Science 2013, 317, 1491.

79. Naylor, R.L.; Falcon, W.P.; Goodman, R.M.; Jahn, M.M.; Sengooba, T.; Tefera, H.; Nelson, R.J. Biotechnology in the developing world: A case for increased investments in orphan crops. Food Policy 2004, 29, 15-44.

80. Falcon, W.P.; Naylor, R.L. Rethinking food security for the 21 st century. Am. J. Agric. Econ. 2005, 87, 1113-1127.

81. Kean, S. Besting Johnny Appleseed. Science 2010, 328, 301-303.

82. The Fagaceae Genome Web Home Page. Available online: http://www.fagaceae.org (accessed on 26 September 2013).

83. Genome Database for Rosaceae Home Page. Available online: http://www.rosaceae.org (accessed on 26 September 2013).

84. International Populus Genome Consortium Home Page. Available online: http://www.ornl.gov/ sci/ipgc (accessed on 26 September 2013).

85. The Generic Genome Browser. Available online: http://hazelnut.cgrb.oregonstate.edu/ (accessed on 26 September 2013). 
86. Jannink, J.L.; Lorenz, A.J.; Iwata, H. Genomic selection in plant breeding: From theory to practice. Brief. Funct. Genomics 2010, 9, 166-177.

87. Tuskan, G.A.; DiFazio, S.P.; Teichmann, T. Poplar genomics is getting popular: The impact of the poplar genome project on tree research. Plant Biol. 2004, 6, 2-4.

88. Tuskan, G.A.; DiFazio, S.; Jansson, S.; Bohlmann, J.; Grigoriev, I.; Hellsten, U.; Putnam, N.; Ralph, S.; Rombauts, S.; Salamov, A.; et al. The genome of black cottonwood, Populus trichocarpa (Torr. \& Gray). Science 2006, 313, 1596-1604.

89. Foster, G.R.; Young, R.A.; Ronkens, M.J.M.; Onstad, C.A. Processes of soil erosion by water. In Soil Erosion and Crop Productivity; Stewart, F.R.F., Stewart, B.A., Eds.; American Society of Agronomy, Crop Science Society of America, Soil Science Society of America: Madison, WI, USA, 1985; pp. 137-162.

90. Troeh, F.R.; Hobbs, J.A.; Donahue, R.L. Soil and Water Conservation, 2nd ed.; Prentice Hall: Englewood Cliffs, NJ, USA, 1991.

91. Sanchez, P.A.; Buresh, R.J.; Leakey, R.R.B. Trees, soils, and food security. Philos. Trans. Biol. Sci. 1997, 352, 949-960.

92. Ryan, D.F.; Bormann, F.H. Nutrient resorption in northern hardwood forests. BioScience 1982, 32, 29-32.

93. Braun, L.C.; Gillman, J.H.; Russelle, M.P. Fertilizer nitrogen timing and uptake efficiency of hybrid hazelnuts in the Upper Midwest, USA. HortScience 2009, 44, 1688-1693.

94. Leakey, R.R.B.; Tomich, T.P. Domestication of tropical trees: From biology to economics and policy. In Agroforestry in Sustainable Agricultural Systems; Buck, L.E., Lassoie, J.P., Fernanders, E.C.M., Eds.; CRC Press: Boca Raton, FL, USA, 1999; pp. 319-338.

95. Cox, T.S.; Bender, M.; Picone, C.; van Tassel, D.L.; Holland, J.B.; Brummer, E.C.; Zoeller, B.E.; Paterson, A.H.; Jackson, W. Breeding perennial grain crops. Crit. Rev. Plant Sci. 2002, 21, 59-91.

96. Cox, T.S.; Glover, J.D.; van Tassel, D.L.; Cox, C.M.; DeHaan, L.R. Prospects for developing perennial grain crops. Bioscience 2006, 56, 649-659.

97. Corley, R.H.V.; Tinker, P.B.H. The Oil Palm; Blackwell Science: Malden, MA, USA 2003.

98. DeHaan, L.R.; van Tassel, D.L.; Cox, T.S. Perennial grain crops: A synthesis of ecology and plant breeding. Renew. Agric. Food Syst. 2005, 20, 5-14.

99. Glover, J.D. Harvested perennial grasslands: Ecological models for farming's perennial future. Agric. Ecosyst. Environ. 2010, 137, 1-2.

100. Glover, J.D.; Culman, S.W.; DuPont, S.T.; Broussard, W.; Young, L.; Mangan, M.E.; Mai, J.G.; Crews, T.E.; DeHaan, L.R.; Buckley, D.H.; et al. Harvested perennial grasslands provide ecological benchmarks for agricultural sustainability. Agric. Ecosyst. Environ. 2010, 137, 3-12.

101. Bennett, E.M.; Carpenter, S.R.; Caraco, N.F. Human impact on erodable phosphorus and eutrophication: A global perspective. Bioscience 2001, 51, 227-234.

102. Crews, T.E. Perennial crops and endogenous nutrient supplies. Renew. Agric. Food Syst. 2005, 20, 25-37.

103. Rabalais, N.N.; Turner, R.E.; Wiseman, W.J., Jr. Gulf of Mexico hypoxia, a.k.a. "The Dead Zone". Annu. Rev. Ecol. Syst. 2002, 33, 235-263. 
104. Funk, C.R.; White, J.F., Jr. Use of natural and transformed endophytes for turf improvement. In Endophyte/Grass Interactions; Hill, N., Bacon, C.W., Eds.; Plenum Press: New York, NY, USA, 1997; pp. 229-239.

105. Postgate, J.R. The Fundamentals of Nitrogen Fixation; Cambridge University Press: New York, NY, USA 1982.

106. Saito, M.; Marumoto, T. Inoculation with arbuscular mycorrhizal fungi: The status quo in Japan and the future prospects. Plant Soil 2002, 244, 273-279.

107. Emerich, D.W.; Krishnan, H.B. Nitrogen Fixation in Crop Production; Agronomy Monograph Series 52; American Society of Agronomy, Crop Science Society of America, Soil Science Society of America (ASA-CSSA-SSSA): Madison, WI, USA, 2009.

108. Fischer, R.A.; Edmeades, G.O. Breeding and cereal yield progress. Crop Sci. 2010, 50, S85-S98.

109. Garnett, T.; Appleby, M.C.; Balmford, A.; Bateman, I.J.; Benton, T.G.; Bloomer, P.; Burlingame, B.; Dawkins, M.; Dolan, L.; Fraser, D.; et al. Sustainable intensification in agriculture: Premises and policies. Science 2013, 341, 33-34.

110. Sanchez, P.A.; Swaminathan, M.S. Cutting world hunger in half. Science 2005, 307, 357-359.

111. Keatinge, J.D.H.; Waliyar, F.; Jamnadas, R.H.; Moustafa, A.; Andrade, M.; Drechsel, P.; Hughes, J.D.A.; Kadirvel, P.; Luther, K. Relearning old lessons for the future of food-By bread alone no longer: Diversifying diets with fruits and vegetables. Crop Sci. 2010, 50, S-51-S-62.

112. Phillips, R.L. Mobilizing science to break yield barriers. Crop Sci. 2010, 50, S-99-S-108.

113. Sanchez, P.A. Soil fertility in Africa. Science 2002, 295, 2019-2020.

114. Lehmann, J.; da Silva, J.P., Jr.; Steiner, C.; Nehls, T.; Zech, W.; Glaser, B. Nutrient availability and leaching in an archaeological Anthrosol and a Ferralsol of the Central Amazon basin: Fertilizer, manure and charcoal amendments. Plant Soil 2003, 249, 343-357.

115. Lehmann, J.; Kern, D.C.; German, L.A.; McCann, J.; Martins, G.C.; Moreira, A. Soil fertility and production potential. In Amazonian Dark Earths: Origin, Properties, Management; Lehmann, J., Kern, D.C., Glaser, B., Woods, W.I., Eds.; Kluwer Academic Publishers: Dordrecht, The Netherlands, 2003; pp. 105-124.

116. Jackson, W. New Roots for Agriculture; University of Nebraska Press: Lincoln, NE, USA, 1980.

117. Wagoner, P. Perennial grain development: Past efforts and potential for the future. Crit. Rev. Plant Sci. 1990, 9, 381-408.

118. Waggoner, P. Perennial grain: New use for intermediate wheatgrass. J Soil Water Conserv. 1990, $45,81-82$.

119. Pimentel, D.; Jackson, W.; Bender, M.; Pickett, W. Perennial grains: An ecology of crops. Interdiscip. Sci. Rev. 1986, 11, 42-49.

120. Jakubziner, M.M. New Wheat Species. In Proceedings of the 1st International Wheat Genetics Symposium, Winnipeg, Canada, 11-15 August 1959; pp. 207-220.

121. Vinall, H.N.; Hein, M.A. Breeding miscellaneous grasses. In Yearbook of Agriculture 1937; U.S. Department of Agriculture: Washington, DC, USA, 1937; p. 1059.

122. Scheinost, P.L.; Lammer, D.L.; Cai, X.; Murray, T.; Jones, S.S. Perennial wheat: The development of a sustainable cropping system for the U.S., Pacific Northwest. Am. J. Altern. Agric. 2001, 16, 147-151. 
123. Bell, L.W.; Byrne, F.; Ewing, M.A.; Wade, L.J. A preliminary whole-farm economic analysis of perennial wheat in an Australian dryland farming system. Agric. Syst. 2008, 96, 166-174.

124. Piper, J.K. Growth and seed yield of three perennial grains within monocultures and mixed stands. Agric. Ecosyst. Environ. 1998, 68, 1-11.

125. Sculte, L.A.; Liebman, M.; Asbjornsen, H.; Crow, T.R. Agroecosystem restoration through strategic integration of perennials. J. Soil Water Conserv. 2006, 61,164A-169A.

126. Pimentel, D.; Cerasale, D.; Stanley, R.C.; Perlman, R.; Newman, E.M.; Brent, L.C.; Mullan, A.; Chang, D.T.I. Annual vs perennial grain production. Agric. Ecosyst. Environ. 2012, 161, 1-9.

127. Glover, J.D.; Reganold, J.P.; Bell, L.W.; Borevitz, J.; Brummer, E.C.; Buckler, E.S.; Cox, C.M.; Cox, T.S.; Crews, T.E.; Culman, S.W.; et al. Increased food and ecosystem security via perennial grains. Science 2010, 328, 1638-1639.

128. Pimentel, D.; Wilson, C.; McCullum, C.; Huang, R.; Dwen, P.; Flack, J.; Tran, Q.; Saltman, T.; Cliff, B. Economic and environmental effects of biodiversity. BioScience 1997, 47, 747-757.

129. Jackson, W. Natural systems agriculture: A truly radical alternative. Agric. Ecosyst. Environ. 2002, 88, 111-117.

130. Tilman, D.J.; Reich, P.B.; Knops, J.; Wedin, D.; Mielke, T.; Lehman, C. Diversity and productivity in a long-term grassland experiment. Science 2001, 294, 843-845.

131. Tilman, D.J.; Reich, P.B.; Knops, J.M.H. Biodiversity and ecosystem stability in a decade long grassland experiment. Nature 2006, 441, 629-632.

132. Rosengarten, F., Jr. The Book of Edible Nuts; Walker \& Company: New York, NY, USA, 1984.

133. Garret, H.E.; Harper, L.S. The science and practice of black walnut agroforestry in Missouri, USA. In Agroforestry in Sustainable Agricultural Systems; Buck, L.E., Lassoie, J.P., Fernanders, E.C.M., Eds.; CRC Press: Boca Raton, FL, USA, 1999; pp. 97-110.

134. Thompson, M.M.; Lagerstedt, H.B.; Mehlenbacher, S.A. Hazelnuts. In Fruit Breeding; Janick, J., Moore, J.N., Eds.; John Wiley and Sons: Hoboken, NJ, USA, 1996; Volume 3, pp. 125-184.

135. Mamadjanov, D.K. Walnut fruit forests and diversity of walnut trees (Juglans regia L.) in Kyrgyzstan. Acta Hort. 2006, 705, 173-176.

136. Alasalvar, C.; Shahidi, F. Tree Nuts: Composition, Phytochemicals, and Health Effects; CRC Press: Boca Raton, FL, USA, 2009.

137. Reid, W. Eastern black walnut: Potential for commercial nut producing cultivars. In Advances in New Crops; Janick, J., Simon, J.E., Eds.; Timber Press: Portland, OR, USA, 1990; pp. 327-331.

138. Thompson, T.E.; Madden, G.D. Pecans. In A Guide to Nut Tree Culture in North America; Fulbright, D.W., Ed.; Northern Nut Growers Association: Hamden, CT, USA, 2003; Volume 1, pp. 79-105.

139. Sparks, D. Pecan Cultivars-The Orchard's Foundation; Pecan Production Innovations: Watkinsville, GA, USA, 1992.

140. Grauke, L.J.; Thompson, T.E. Pecans and hickories. In Fruit Breeding; Janick, J., Moore, J.N., Eds.; John Wiley and Sons: Hoboken, NJ, USA, 1996; pp. 185-240.

141. McGranahan, G.; Leslie, C. Walnuts (Juglans). In Genetic Resources of Temperate Fruit and Nut Crops; Moore, J.N., Ballington, J.R., Eds.; International Society for Horticultural Science: Leuven, Belgium, 1991; pp. 907-951. 
142. Tsao, R.; Li, L. Phytochemical profiles and potential health benefits of heartnut (Juglans ailantifolia var. cordiformis): A comparison with the common walnut (Juglans regia L.). In Tree Nuts-Composition, Phytochemicals and Health Effects; Alasalvar, C., Shahidi, F., Eds.; CRC Press: Boca Raton, FL, USA, 2009; pp. 237-248.

143. McGranahan, G.; Leslie, C. Breeding walnuts (Juglans regia). In Breeding Plantation Tree Crops: Temperate Species; Jain, S.M., Priyadarshan, P.M., Eds.; Springer: New York, NY, USA, 2009; pp. 254-278.

144. Leslie, C.A.; McGranahan, G.H. The origin of the walnut. In Walnut Production Manual; Ramos, D., Ed.; University of California Agriculture and Natural Resources Publications: Richmond, CA, USA, 1998; pp. 3-7.

145. O'Rourke, F.L.S. The Carpathian (Persian) walnut. In Handbook of North American Nut Trees; Jaynes, R.A., Ed.; Northern Nut Growers Association: Geneva, NY, USA, 1969; pp. 232-239.

146. McGranahan, G.H.; Leslie, C. Advances in genetic improvement of walnut at the University of California, Davis. Acta Hort 2006, 705, 117-122.

147. Thompson, M.M. Exploration and exploitation of new fruit and nut germplasm. In New Crops; Janick, J., Simon, J.E., Eds.; John Wiley and Sons: New York, NY, USA, 1993; pp. 155-160.

148. Popov, S.I. Diversity of walnut in the walnut-fruit forests and its practical value. In Biodiversity and Sustainable Use of Kyrgyzstan's Walnut-Fruit Forests; Blaser, J., Carter, J., Gilmour, D., Eds.; International Union for Conservation of Nature (IUCN): Gland, Switzerland; and Cambridge, UK; INTERCOOPERATION: Bern, Switzerland 1995; pp. 117-119.

149. Germain, E.; Delort, F.; Kanivets, V. Precocious maturing walnut populations originating from Central Asia: Their behavior in France. Acta Hort 1997, 422, 83-89.

150. Forde, H.I.; McGranahan, G.H. Walnuts. In Fruit Breeding; Janick, J., Moore, J.N., Eds.; John Wiley and Sons: Hoboken, NJ, USA, 1996; Volume 3, pp. 241-273.

151. Vahdati, K.; McKenna, J.R.; Dandekar, A.M.; Leslie, C.A.; Uratsu, S.L.; Hackett, W.P.; Negri, P.; McGranahan, G.H. Rooting and other characteristics of a transgenic walnut hybrid (Juglans hindsii $\times$ J. regia) rootstock expressing rolABC. J. Am. Soc. Hortic. Sci. 2002, 127, 724-728.

152. Dangl, G.S.; Woeste, K.; Aradhya, M.K.; Koehmstedt, A.; Simon, C.; Potter, D.; Leslie, C.A.; McGranahan, G. Characterization of 14 microsatellite markers for genetic analysis and cultivar identification of walnut. J. Am. Soc. Hortic. Sci. 2005, 130, 348-354.

153. Molnar, T.J.; Zaurov, D.E.; Capik, J.M.; Eisenman, S.W.; Ford, T.; Nikolyi, L.V.; Funk, C.R. Persian walnuts (Juglans regia L.) in Central Asia. Annu. Rep. North. Nut. Grow. Assoc. 2011, $101,56-69$.

154. Pollock, S.; Perez, A. Fruit and Tree Nuts Situation and Outlook Yearbook; U.S. Department of Agriculture: Washington, DC, USA, 2005.

155. Simopoulos, A.P. Omega-3 fatty acids in wild plants, nuts and seeds. Asia Pac. J. Clin. Nutr. 2002, 11, S163-S173.

156. Gleason, H.A.; Cronquist, A. Manual of Vascular Plants of Northeastern United States and Adjacent Canada; New York Botanical Garden: Bronx, NY, USA, 1998.

157. Prindle, J. Hammons Products Company, Stockton, MO, USA. Black walnut crop purchased by Hammons Products Company 2007-2009. Personal communication, 16 July 2010. 
158. Chenoweth, B. Black Walnut-The History, Use, and Unrealized Potential of a Unique American Renewable Natural Resource; Sagamore Publishing: Champaign, IL, USA, 1995.

159. Victory, E.R. History of black walnut genetics research in North America. In Black Walnut in a New Century, Proceedings of the 6th Walnut Council Research Symposium, Lafayette, IN, USA, 25-28 July 2004; Michler, C.H., Pijut, P.M., van Sambeek, J.W., Coggeshall, M.V., Seifert, J., Woeste, K., Overton, R., Ponder, F., Jr., Eds.; Genetic Technical Report NC-243, North Central Research Station, Forest Service, U.S. Department of Agriculture: Washington, DC, USA, 2004; pp. 1-8.

160. Beineke, W.F. Twenty years of black walnut genetic improvement at Purdue University. North. J. Appl. For. 1989, 6, 68-71.

161. Victory, E.R.; Glaubitz, J.C.; Rhodes, O.E., Jr.; Woeste, K.E. Genetic homogeneity in Juglans nigra (Juglandaceae) at nuclear microsatellites. Am. J. Bot. 2006, 93, 118-126.

162. Reid, W.; Coggeshall, M.V.; Hunt, K.L. Cultivar Evaluation and Development for Black Walnut Orchards. In Black Walnut in a New Century, Proceedings of the 6th Walnut Council Research Symposium, Lafayette, IN, USA, 25-28 July 2004; Michler, C.H., Pijut, P.M., van Sambeek, J.W., Coggeshall, M.V., Seifert, J., Woeste, K., Overton, R., Ponder, F., Jr., Eds.; Genetic Technical Report NC-243, North Central Research Station, Forest Service, U.S. Department of Agriculture: Washington, DC, USA; pp. 18-24.

163. Reid, W.; Coggeshall, M.; Garret, H.E.; van Sambeek, J. Growing Black Walnut for Nut Production. Available online: http://www.centerforagroforestry.org/pubs/walnutNuts.pdf (accessed on 27 March 2013).

164. Coggeshall, M.V. Black walnut cultivar improvement program at the University of Missouri. Annu. Rep. North. Nut. Grow. Assoc. 2002, 93, 93-96.

165. Woeste, K.E.; McKenna, J.R. Walnut Genetic Improvement at the Start of a New Century. In Black Walnut in a New Century, Proceedings of the 6th Walnut Council Research Symposium, Lafayette, IN, USA, 25-28 July 2004; Michler, C.H., Pijut, P.M., van Sambeek, J.W., Coggeshall, M.V., Seifert, J., Woeste, K., Overton, R., Ponder, F., Jr., Eds.; U.S. Department of Agriculture: Washington, DC, USA, 2004; pp. 9-17.

166. The Northern Nut Growers Association Home Page. Available online: http://www.nutgrowing.org (accessed on 27 March 2013).

167. Hanson, B. Black walnut cultivar performance. Annu. Rep. North. Nut. Grow. Assoc. 2003, 94, $120-132$.

168. Gordon, J.H. Nut Growing Ontario Style; Society of Ontario Nut Growers: Niagara-on-the-Lake, Ontario, Canada, 1993.

169. Utley, C.; Nguyen, T.; Roubtsova, T.; Coggeshall, M.; Ford, T.M.; Grauke, L.J.; Graves, A.D.; Leslie, C.A.; McKenna, J.; Woeste, K.; et al. Susceptibility of walnut and hickory species to Geosmithia morbida. Plant Dis. 2013, 97, 601-607.

170. Brison, F.R. Pecan Culture; Capital Printing: Austin, TX, USA, 1974.

171. Grauke, L.J. Yunnan hickory. Annu. Rep. North. Nut. Grow. Assoc. 2006, 97, 57-69.

172. MacDaniels, L.H. Hickories. In Nut Tree Culture in North America; Jaynes, R.A., Ed.; Northern Nut Growers Association: Hamden, CT, USA, 1979; pp. 35-50. 
173. Potts, B.M.; Dungey, H.S. Interspecific hybridization of Eucalyptus: Key issues for breeders and geneticists. New For. 2004, 27, 115-138.

174. Thompson, T.E.; Grauke, L.J. Pecans and other hickories (Carya). In Genetic Resources of Temperate Fruit and Nut Crops; Moore, J.N., Ballington, J.R., Eds.; International Society for Horticultural Science: Wageningen, The Netherlands, 1991; pp. 837-904.

175. Mehlenbacher, S.A. Hazelnuts (Corylus). In Genetic Resources of Temperate Fruit and Nut Crops; Moore, J.N., Ballington, J.R., Eds.; International Society for Horticultural Science: Leuven, Belgium, 1991; 789-836.

176. Erdogan, V.; Mehlenbacher, S.A. Interspecific hybridization in hazelnut (Corylus). J. Am. Soc. Hortic. Sci. 2000, 125, 489-497.

177. Molnar, T.J.; Goffreda, J.C.; Funk, C.R. Developing hazelnuts for the eastern United States. Acta Hortic. 2005, 68, 609-617.

178. United States Department of Agriculture Web Page. National Clonal Germplasm Repository Database. Available online: http://www.ars.usda.gov/Main/docs.htm?docid=11035 (accessed on 27 March 2013).

179. Fuller, A.S. The Nut Culturist; Orange Judd Company: New York, NY, USA, 1896.

180. Mehlenbacher, S.A.; Thompson, M.M.; Cameron, H.R. Occurrence and inheritance of resistance to eastern filbert blight in "Gasaway" hazelnut. HortScience 1991, 26, 410-411.

181. Lunde, C.F.; Mehlenbacher, S.A.; Smith, D.C. Survey of hazelnut cultivars for response to eastern filbert blight inoculation. HortScience 2000, 35, 729-731.

182. Chen, H.; Mehlenbacher, S.A.; Smith, D.C. Hazelnut accessions provide new sources of resistance to eastern filbert blight. HortScience 2007, 42, 466-469.

183. Molnar, T.J.; Zaurov, D.E.; Goffreda, J.C.; Mehlenbacher, S.A. Survey of hazelnut germplasm from Russia and Crimea for response to eastern filbert blight. HortScience 2007, 42, 51-56.

184. Molnar, T.J.; Goffreda, J.C.; Funk, C.R. Survey of Corylus resistance to Anisogramma anomala from different geographic locations. HortScience 2010, 45, 832-836.

185. Mehlenbacher, S.A.; Smith, D.C.; McCluskey, R.L. "Yamhill" hazelnut. HortScience 2009, 44, 845-847.

186. Mehlenbacher, S.A.; Smith, D.C.; McCluskey, R.L. "Jefferson" hazelnut. HortScience 2011, 46, $662-664$.

187. Mehlenbacher, S.A. Hazelnuts. In A Guide to Nut Tree Culture in North America; Fulbright, D.W., Ed.; Northern Nut Growers Association: Hamden, CT, USA, 2003; Volume 1, pp. 183-215.

188. Ebrahem, K.S.; Richardson, D.G.; Tetley, R.M.; Mehlenbacher, S.A. Oil content, fatty acid composition, and vitamin E concentration of 17 hazelnut varieties, compared to other types of nuts and oil seeds. Acta Hortic. 1994, 351, 685-692.

189. Leakey, R.R.B. Potential for novel food products from agroforestry trees: A review. Food Chem. 1999, 66, 1-14.

190. Breeding Plantation Tree Crops: Tropical Species; Jain, S.M., Priyadarshan, P.M., Eds.; Springer: New York, NY, USA, 2009.

191. Batugal, P.; Bourdeix, R.; Baudouin, L. Coconut breeding. In Breeding Plantation Tree Crops: Temperate Species; Jain, S.M., Priyadarshan, P.M., Eds.; Springer: New York, NY, USA, 2009; pp. 327-375. 
192. Sambanthamurthi, R.; Singh, R.; Kadir, A.P.G.; Abdullah, M.O.; Kushairi, A. Opportunities for the oil palm via breeding and biotechnology. In Breeding Plantation Tree Crops: Tropical Species; Jain, S.M., Priyadarshan, P.M., Eds.; Springer: New York, NY, USA, 2009; pp. 377-421.

193. Leakey, R.R.B.; Newton, A.C. Domestication of "Cinderella" species as the start of a woody-plant revolution. In Tropical Trees: The Potential for Domestication and the Rebuilding of Forest Resources; Leakey, R.R., Newton, A.C., Eds.; HMSO: London, UK, 1994; pp. 3-6.

194. Brewbaker, J.L.; Sorenssen, C.T. Domestication of lesser-known species of the genus Leucaena. In Tropical Trees: The Potential for Domestication and the Rebuilding of Forest Resources, Leakey, R.R., Newton, A.C., Eds.; HMSO: London, UK, 1994; pp. 195-204.

195. Pandey, V.C.; Kumar, A. Leucaena leucocephala: An underutilized plant for pulp and paper production. Genet. Resour. Crop Evol. 2013, 60, 1165-1171.

196. Nirsatmanto, A.; Leksono, B.; Kurinobu, S.; Shiraishi, A. Realized genetic gain observed in second generation seedling seed orchards of Acacia mangium in South Kalimantan, Indonesia. J. For. Res. 2004, 9, 265-269.

197. Brockwell, J.; Searle, S.D.; Jeavons, A.C.; Waayers, M. Nitrogen Fixation in Acacias: An Untapped Resource for Sustainable Plantations, Farm Forestry and Land Reclamation; ACIAR Monograph Series 115; Australian Centre for International Agricultural Research (ACIAR): Canberra, Australia, 2005; pp. 1-132.

198. Eldridge, K.; Davidson, J.; Hardwood, C.; van Wyk, G. Eucalypt Domestication and Breeding; Oxford University Press: Oxford, UK, 1994.

199. Camphinos, E. Sustainable plantations of high-yield shape Eucalyptus trees for production of fiber: The Aracruz case. New For. 1999, 7, 129-143.

200. Calder, I.R.; Risier, P.T.W.; Prasanna, K.T.; Parameswarappa, S. Eucalyptus water use greater than rainfall input-A possible explanation from southern India. Hydrol. Earth Syst. Sci. 1997, 1, 249-256.

201. Geary, T.F. Afforestation in Uruguay: Study of a changing landscape. J. For. 2001, 99, 35-39.

202. Jawjit, W.; Kroeze, C.; Soontaranun, W.; Hordijk, L. Options to reduce the environmental impact by eucalyptus-based Kraft pulp industry in Thailand: Model description. J. Clean. Prod. 2007, $15,1827-1839$.

203. Jawjit, W.; Kroeze, C.; Soontaranun, W.; Hordijk, L. An analysis of the environmental pressure exerted by the eucalyptus-based Kraft pulp industry in Thailand. Environ. Dev. Sustain. 2006, 8, 289-311.

204. Liu, H.; Li, J. The study of ecological oproblems of Eucalyptus plantation and sustainable development in Maoming Xiaoliang. J. Sustain. Dev. 2010, 3, 197-201.

205. Binkley, D.; Stape, J.L. Sustainable Management of Eucalyptus Plantations in a Changing World. In Proceedings of the IUFRO Conference-Eucalyptus in a Changing World, Borralho, N.M.G., Pereira, J.S., Marques, C., Coutinho, J., Madeira, M., Tomé, M., Eds.; Aveiro, Portugal, 11-15 October 2004.

206. Bragança, M.; DeSouza, O.; Zanuncio, J.C. Environmental heterogeneity as a strategy for pest management in Eucalyptus plantations. For. Ecol. Manag. 1998, 102, 9-12.

207. Moffat, A.S. Resurgent forests can be greenhouse gas sponges. Science 1997, 277, 315-316. 
208. Fearnside, P.M. Global warming and tropical land-use change: Greenhouse gas emissions from biomass burning, decomposition and soils in forest conversion, shifting cultivation and secondary vegetation. Clim. Chang. 2000, 46, 115-158.

209. The Global Partnership on Forest and Landscape Restoration Web Page. Available online: http://www.ideastransformlandscapes.org/ (accessed on 26 September 2013)

210. Murgueitio, E.; Calle, Z.; Uribe, F.; Calle, A.; Solorio, B. Native trees and shrubs for productive rehabilitation of tropical cattle ranching lands. For. Ecol. Manag. 2011, 261, 1654-1663.

211. Calle, Z.; Murgueitio, E.; Chará, J. Integrating forestry, sustainable cattle ranching and landscape restoration. Unasylva 239 2012, 63, 31-40.

212. Kahn, P.C.; Molnar, T.; Zhang, G.G.; Funk, C.R. Investing in perennial crops to sustainably feed the world. Issues Sci. Technol. 2011, 27, 75-81.

213. Forest Stewardship Council Home Page. Available online: http://www.fsc.org/en (accessed on 27 March 2013).

214. Roundtable on Sustainable Palm Oil (RSPO) Home Page. Roundtable on Sustainable Palm Oil Production. Available online: http://www.rspo.org/ (accessed on 27 March 2013).

215. World Bank Web Page. World Development Report 2008: Agriculture for Development. Available online: http://siteresources.worldbank.org/INTWDR2008/Resources/2795087-1192111580172/ WDROver2008-ENG.pdf (accessed on 27 March 2013).

216. Deane, C.; Ejeta, G.; Rabbinge, R.; Sayer, J. Science for development: Mobilizing global partnerships. Crop Sci. 2010, 50, v-viii.

(C) 2013 by the authors; licensee MDPI, Basel, Switzerland. This article is an open access article distributed under the terms and conditions of the Creative Commons Attribution license (http://creativecommons.org/licenses/by/3.0/). 